\title{
The Jurassic of Kuhn $\varnothing$, North-East Greenland
}

\author{
Per C. Alsgaard, Vince L. Felt, Henrik Vosgerau and Finn Surlyk
}

The Middle-Upper Jurassic succession of Kuhn $\varnothing$, North-East Greenland accumulated in a major half-graben and is an excellent analogue for the subsurface of the mid-Norwegian shelf. On Kuhn $\varnothing$, peneplaned crystalline basement was incised by a drainage system during a major base-level lowstand, probably in late Early or early Middle Jurassic times. It was filled with fluvial conglomerates of the newly defined Middle Jurassic Bastians Dal Formation during subsequent base-level rise. As sea level continued to rise, precursor-peat of the coals of the Muslingebjerg Formation formed in swamps which covered the conglomerates and filled the remaining space of the incised valley system. The valley and interfluve areas were flooded in Late Bathonian - Callovian times and tidally-dominated, shallow marine sandstones of the Pelion Formation were deposited on top of the valley fill and over the adjacent basement peneplain. These sandstones are overlain by the newly defined shallow marine Oxfordian Payer Dal Formation which is subdivided into a lower unit and an upper unit, separated by a major drowning surface. The Payer Dal Formation sands were flooded in the Late Jurassic and organic-rich, offshore mudstones of the Bernbjerg Formation were deposited. The Jurassic succession of Kuhn $\varnothing$ can thus be subdivided into large-scale sedimentary units separated by major drowning surfaces. They are of regional extent, and in combination with biostratigraphic and ${ }^{87} \mathrm{Sr} /{ }^{86} \mathrm{Sr}$ isotope data they allow the correlation of the sedimentary units on Kuhn $\varnothing$ with more offshore deposits to the south in Wollaston Forland and more landwards successions to the north in Hochstetter Forland.

Petrographically, the trough cross-bedded sandstones of the Pelion Formation and the lower unit of the Payer Dal Formation include both calcite-cemented and poorly cemented quartz sandstones. The calcite cement was derived from dissolution of abundant calcareous fossils and forms concretionary horizons. The upper unit of the Payer Dal Formation mainly consists of weaklycemented quartz sandstones with porosities around 30\%. The sandstones of the Pelion and Payer Dal Formations on Kuhn $\varnothing$ are petrographically very similar to Jurassic sandstones from the midNorwegian shelf and the Barents Sea with regard to original mineralogical composition, sorting and grain size. The Bernbjerg Formation mudstones are comparable to the Upper Jurassic source rock of the mid-Norwegian shelf and the Barents Sea, but have lower hydrogen index (HI) values due to terrigenous input in a relatively proximal setting. Coals of the Muslingebjerg Formation have significant source rock potential with measured HI values up to 700, kerogen types II-III and total organic carbon (TOC) values above 50\%.

Keywords: Kuhn $\varnothing$, North-East Greenland, Middle-Upper Jurassic, lithostratigraphy, sedimentology, petrography, source rocks

\footnotetext{
P.C.A.* \& V.L.F. $\neq$ Amoco Norway Oil Company. Present addresses: "Norsk Hydro, N-O246 Oslo, Norway. ‡ BP Amoco - Egypt, 14, Road 252, Digla, Maadi Cairo, Egypt; P.O. Box 2409. E-mail: per.chr.alsgaard@hydro.com

H.V., Geological Survey of Denmark and Greenland, Geocenter Copenhagen, Øster Voldgade 10, DK-1350 Copenhagen K, Denmark.

F.S., Geological Institute, University of Copenhagen, Geocenter Copenhagen, Øster Voldgade 10, DK-1350 Copenbagen K, Denmark.
} 
The proximity of North-East Greenland to the midNorwegian shelf during Mesozoic times makes it an obvious candidate in the search for exposed analogues of reservoir facies, source rocks and structural frame-

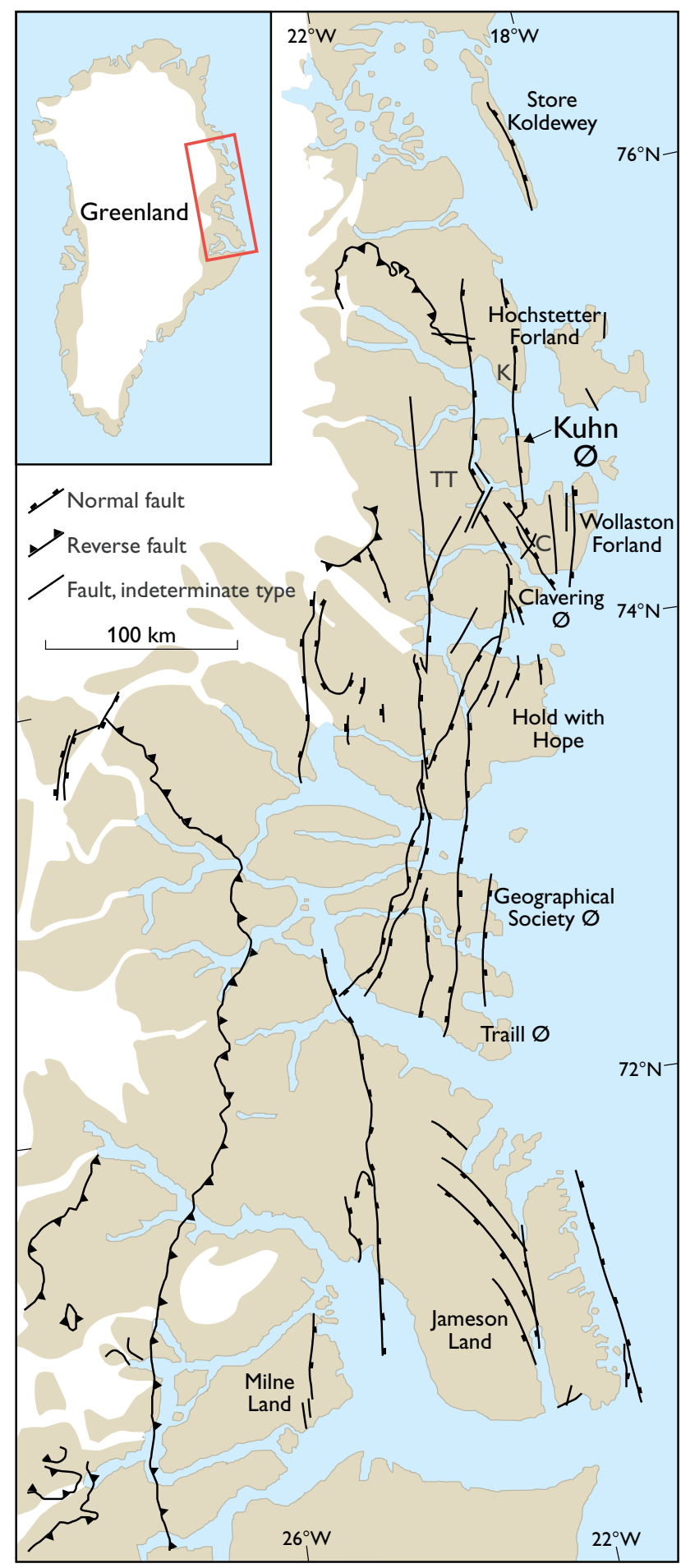

Fig. 1. Map of the East Greenland basin complex showing fault zones active during Mesozoic times. C, Cardiocerasdal; K, Kulhus, Søndre Muslingebjerg; TT, Th. Thomsen Land. work of the potential hydrocarbon systems. Kuhn $\varnothing$, in particular, may be analogous to areas on the midNorwegian shelf that are characterised by a relatively thin Jurassic succession between basement and the 'base-Cretaceous unconformity' that accumulated adjacent to a subaerially exposed landmass.

The 'Wollgan project' was a co-operative research project involving Statoil, Saga, Amoco, the Norwegian Petroleum Directorate (NPD) and the Geological Institute of the University of Copenhagen. The three weeks of field work in 1994 focused on the Jurassic early rift and rift-climax successions of Kuhn $\varnothing$ and Wollaston Forland, and the Cretaceous post-rift deposits of Wollaston Forland (Figs 1, 2). Within this framework, geologists from Amoco and the University of Copenhagen studied the Jurassic of Kuhn $\varnothing$, forming the basis for this paper. The field work took place in central and south Kuhn $\varnothing$ (Figs 3-5). The geology was mapped onto non-orthographic vertical aerial photographs enlarged to a scale of 1:25 000 .

The Middle-Late Jurassic structural development of tilted fault blocks in the Kuhn $\varnothing-$ Wollaston Forland region was first unravelled by Vischer (1943). Maync (1947) documented the Jurassic and Lower Cretaceous sections of Kuhn $\varnothing$ and identified many good outcrops. The geological map by Koch \& Haller (1971) gives a general structural and stratigraphic overview, and a lithostratigraphic scheme was erected by Surlyk (1977).

\begin{tabular}{|c|c|c|c|c|}
\hline Series & $\begin{array}{l}\text { Super- } \\
\text { group }\end{array}$ & Group & Formation & Member \\
\hline \multirow{6}{*}{$\begin{array}{l}\text { Lower } \\
\text { Cretaceous }\end{array}$} & \multirow{14}{*}{ 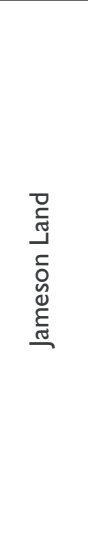 } & \multirow{7}{*}{$\begin{array}{l}\text { Wollaston } \\
\text { Forland }\end{array}$} & \multirow{4}{*}{ Palnatokes Bjerg } & Rødryggen \\
\hline & & & & Albrechts Bugt \\
\hline & & & & Falske Bugt \\
\hline & & & & Young Sund \\
\hline & & & \multirow{3}{*}{$\begin{array}{l}\text { Lindemans } \\
\text { Bugt }\end{array}$} & Niesen \\
\hline & & & & Rigi \\
\hline \multirow{5}{*}{$\begin{array}{l}\text { Upper } \\
\text { Jurassic }\end{array}$} & & & & Laugeites Ravine \\
\hline & & \multirow{2}{*}{$\begin{array}{c}\text { Hall } \\
\text { Bredning }\end{array}$} & \multirow{2}{*}{ Bernbjerg } & \\
\hline & & & & Ugpik Ravine \\
\hline & & \multirow{5}{*}{ Vardekløft } & Jakobsstigen & \\
\hline & & & Payer Dal & \\
\hline \multirow{3}{*}{$\begin{array}{l}\text { Middle } \\
\text { Jurassic }\end{array}$} & & & Pelion & Spath Plateau \\
\hline & & & Muslingebjerg & \\
\hline & & & Bastians Dal & \\
\hline
\end{tabular}

Fig. 2. Stratigraphic scheme for the Jurassic-Cretaceous of Hold with Hope, Wollaston Forland, Kuhn $\varnothing$ and Hochstetter Forland; slightly modified from Surlyk (2003, this volume, fig. 5). Note that the Jakobsstigen Formation is restricted to Wollaston Forland and Th. Thomsen Land and is not recognised on Kuhn $\varnothing$. It is laterally equivalent to the lower Payer Dal Formation on Kuhn $\varnothing$ (see Fig. 23). 


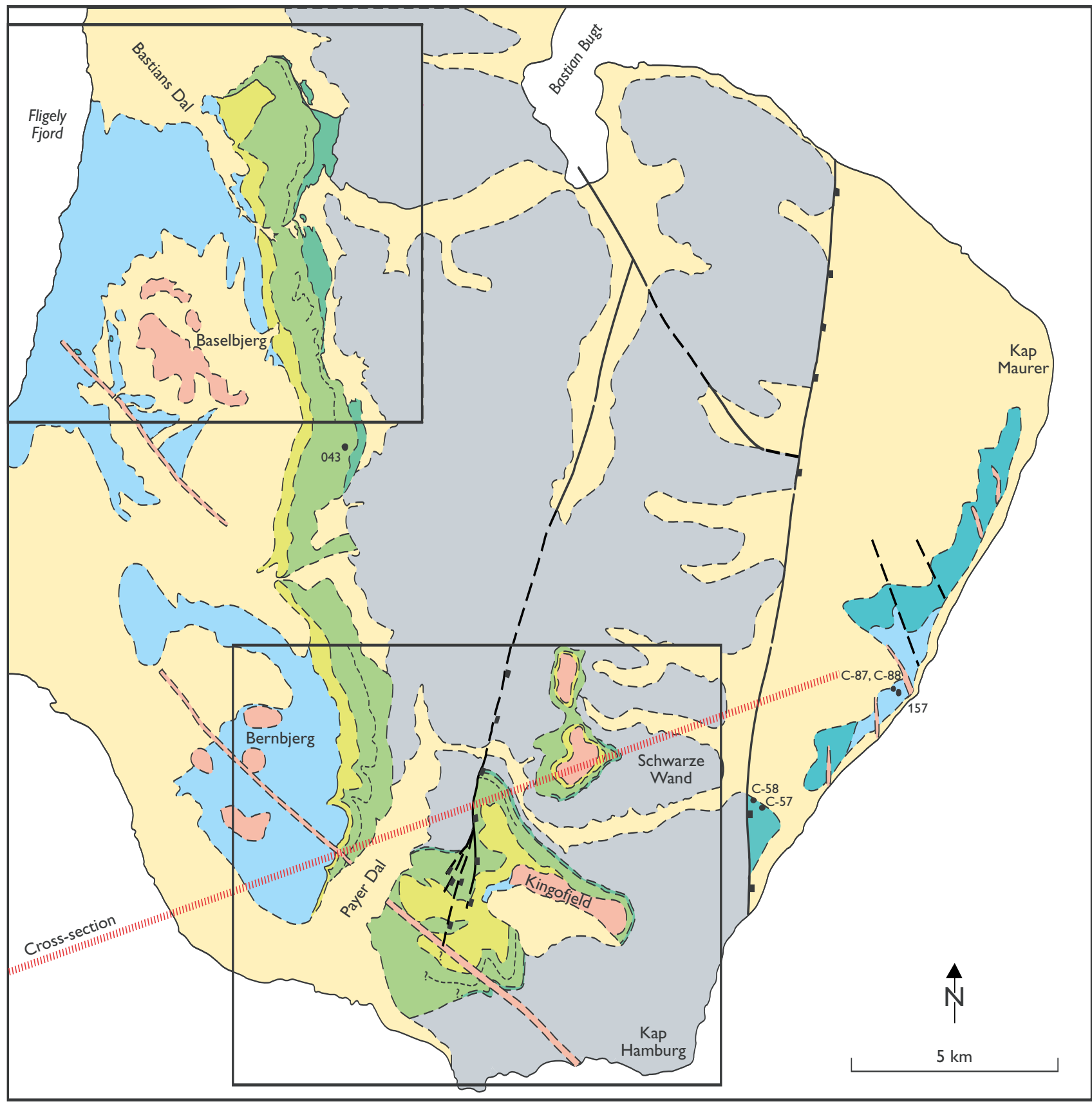

Middle-Upper Jurassic

Quaternary alluvium

Palaeogene

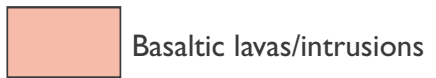

Upper Jurassic - Lower Cretaceous

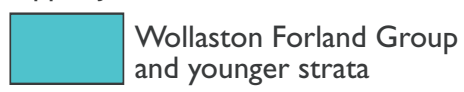

Upper Jurassic

Bernbjerg Formation
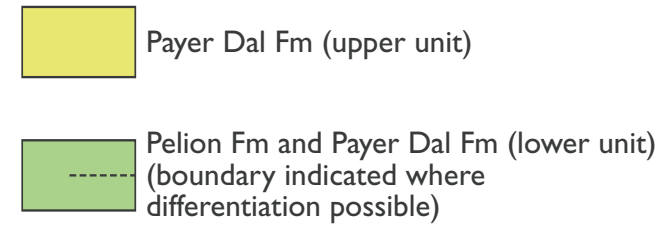

(boundary indicated wher

Bastians Dal and Muslingebjerg Fms

Basement

Caledonian crystalline basement
- Sample locality

Measured section

Stratigraphic boundaries observed

' Stratigraphic boundaries inferred

Normal fault, tick on downthrow side

$\therefore$ Inferred fault line

$\triangle$ Peaks

$\lambda$ Strike and dip

Fig. 3. Geological map of Kuhn $\varnothing$, East Greenland. The cross-section indicated is shown in Fig. 7. The two areas outlined show the location of the detailed maps in Figs 4, 5. Based on Koch \& Haller (1971) and own data. 


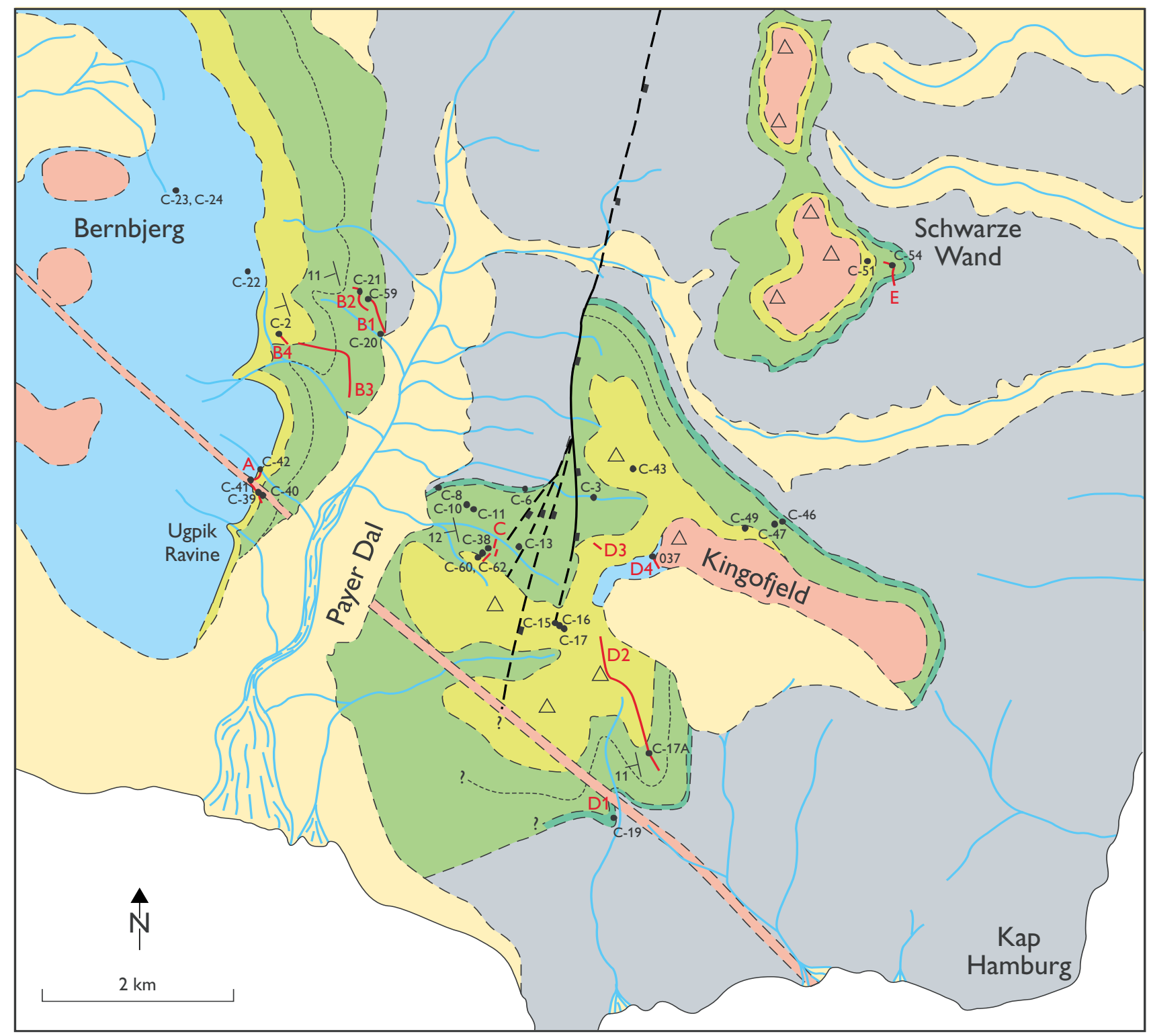

Fig. 4. Geological map of the Payer Dal area, south Kuhn $\varnothing$ (see Fig. 3). Based on Koch \& Haller (1971) and own data. For legend, see Fig. 3.

Surlyk \& Clemmensen (1983) interpreted the sedimentary succession in terms of a series of backstepping units reflecting the combined effects of progressive rifting and eustatic sea-level rise. Surlyk (1991) interpreted the Middle-Upper Jurassic succession within a low order sequence stratigraphic framework.

This paper presents a revised lithostratigraphic scheme for the Jurassic of Kuhn $\varnothing$ and two new formations are defined, the fluvial Bastians Dal Formation at the base of the succession and the shallow marine Payer Dal Formation (Fig. 2). The Jurassic sediments are described according to their facies, diagenesis and geochemistry, and an interpretation of the depositional environments is presented. Thickness and facies changes from the crest of a tilted fault block in the east (Schwarze Wand) to a relatively deeper structural setting on the hangingwall in the west (west Payer Dal) is illustrated by an east-west stratigraphic profile through southern Kuhn $\varnothing$, parallel to structural dip. Finally, the Jurassic succession of Kuhn $\varnothing$ is compared to more offshore contemporaneous deposits to the south in Wollaston Forland and a more landwards succession to the north in Hochstetter Forland described by Clemmensen \& Surlyk (1976), Surlyk (1977, 1978a), Surlyk \& Clemmensen (1983), Bojesen-Koefoed et al. (1996), Petersen et al. (1998) and Vosgerau et al. (2000). 


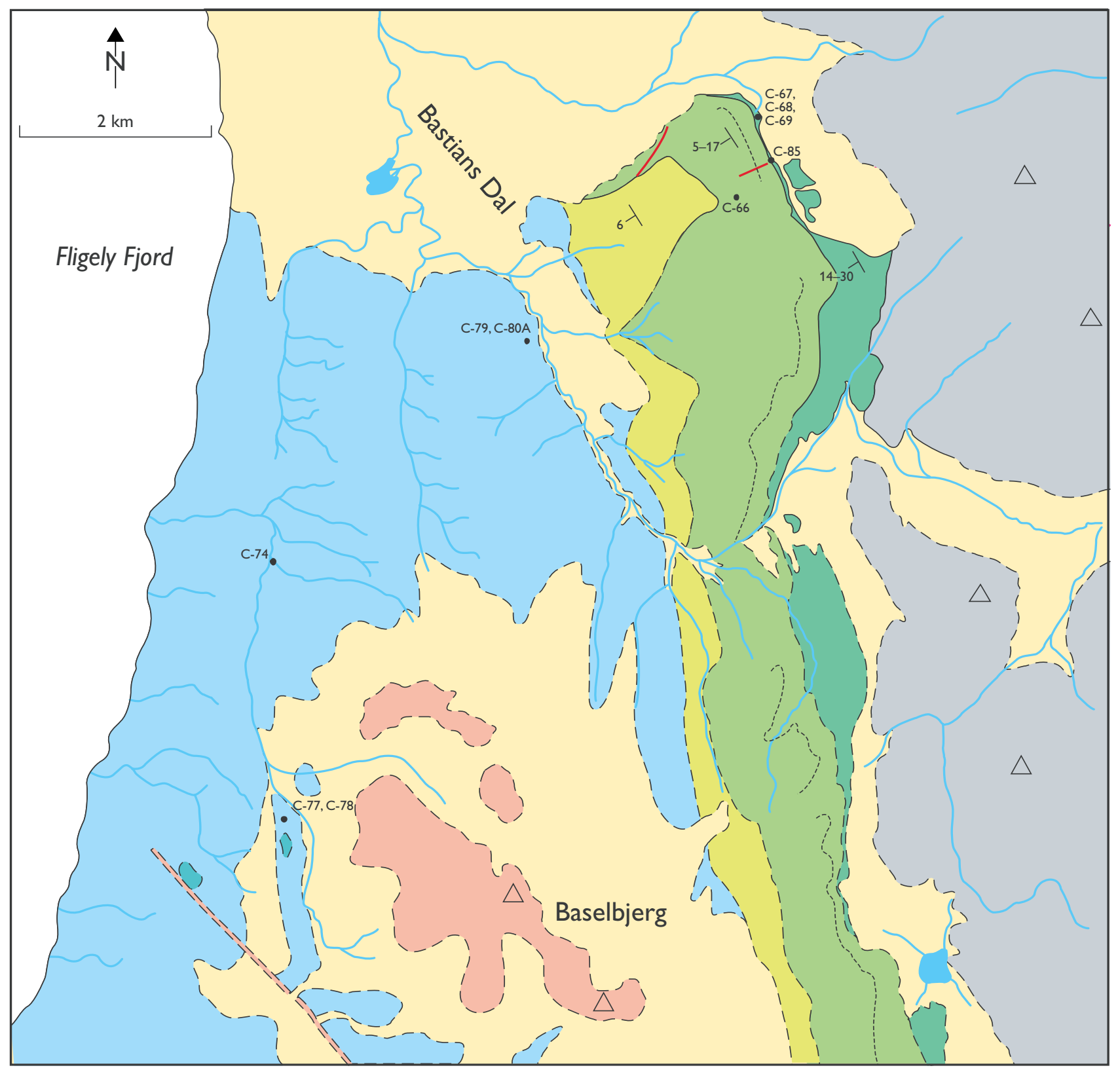

Fig. 5. Geological map of the Bastians Dal area, central Kuhn $\varnothing$ (see Fig. 3). Based on Koch \& Haller (1971) and own data. For legend, see Fig. 3.

\section{Geological setting}

The Jurassic succession of Kuhn $\varnothing$ was deposited in the northern part of the Wollaston Forland basin of North-East Greenland, which was situated on the western margin of the Jurassic rift complex between Greenland and Norway. Deposition took place in a rift-controlled embayment which was open to marine circulation towards the south (Fig. 6). Regional sediment transport was axial from north to south, down a low-gradient basin floor sloping to the south (Surlyk 1977, 1990, 1991; Surlyk \& Clemmensen 1983).

The island of Kuhn $\varnothing$ is positioned on the hangingwall slope of a tilted fault block, within which Middle Jurassic strata rest unconformably on crystalline basement (Fig. 7). The Jurassic succession thickens westwards into the half-graben and onlaps eastwards onto Caledonian basement. The Middle-Upper Jurassic succession of Kuhn $\varnothing$ comprises, in ascending order, the Bastians Dal, Muslingebjerg, Pelion, Payer Dal and 


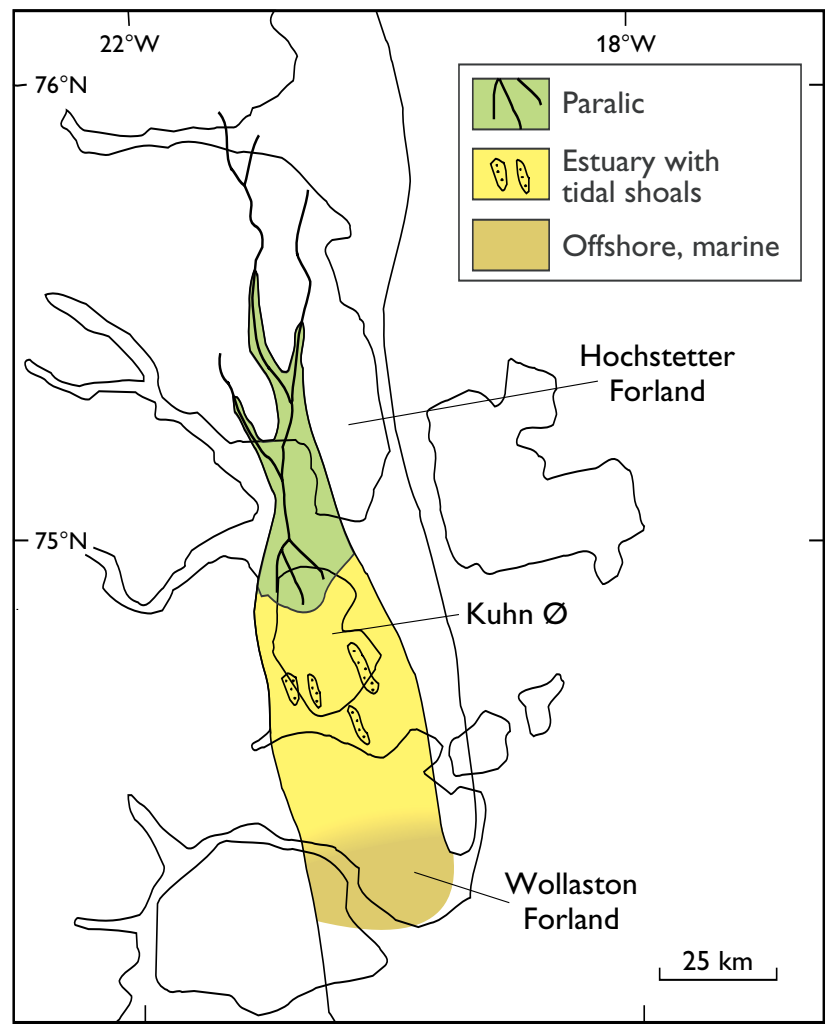

Fig. 6. Late Bathonian - Callovian palaeogeography of the Wollaston Forland basin (modified from Surlyk \& Clemmensen 1983).

Bernbjerg Formations which form a series of backstepping early rift units separated by major drowning surfaces (Figs 2, 8; Surlyk 1977, 1991; Surlyk \& Clemmensen 1983). It is overlain by conglomerate-dominated rift-climax deposits of the Wollaston Forland Group of latest Jurassic - earliest Cretaceous age (Surlyk 1978b).

\section{Methods}

The Jurassic sediments were studied in southern Kuhn $\varnothing$ around the valley of Payer Dal and in central Kuhn $\varnothing$ around the valley of Bastians Dal (Figs 3-5). The exposed section extends from the basal unconformity overlying crystalline basement, through the Bastians Dal, Muslingebjerg, Pelion, Payer Dal and Bernbjerg Formations (Figs 8-11). The outcrops are partially covered by scree slopes, such that the sections are composite and combined from smaller segments.

A total of 93 samples were collected on Kuhn $\varnothing$ for petrographic, geochemical and biostratigraphic analysis. To avoid the effects of surface weathering, geochemical samples were normally collected at depths of $30 \mathrm{~cm}$ into the permafrost, or almost one metre from the surface. A total of 33 samples were evaluated biostratigraphically, ten for calcareous nannoplankton, nineteen for foraminifers and four for ammonites (Table 1). Dinocysts are absent in the non-marine Bastians Dal Formation; the marine Pelion Formation and the lower Payer Dal Formation show higher dinocyst diversities than the upper Payer Dal Formation. The samples analysed for micropalaeontology were barren of nannoplankton and there were only a few poorly preserved foraminifers with long stratigraphic age ranges. Ammonites were only found in the Bernbjerg Formation. Previous biostratigraphic data (Sykes \& Surlyk 1976; Surlyk 1977) were utilised in dating and correlating the Jurassic succession on Kuhn $\varnothing$ with adjacent areas within the Wollaston Forland basin. In addition, strontium isotope analysis has been performed on a few belemnites from the Jurassic succession in Payer Dal and from a more offshore succession in the Cardiocerasdal

$\operatorname{SW}\left(250^{\circ}\right)$

NE

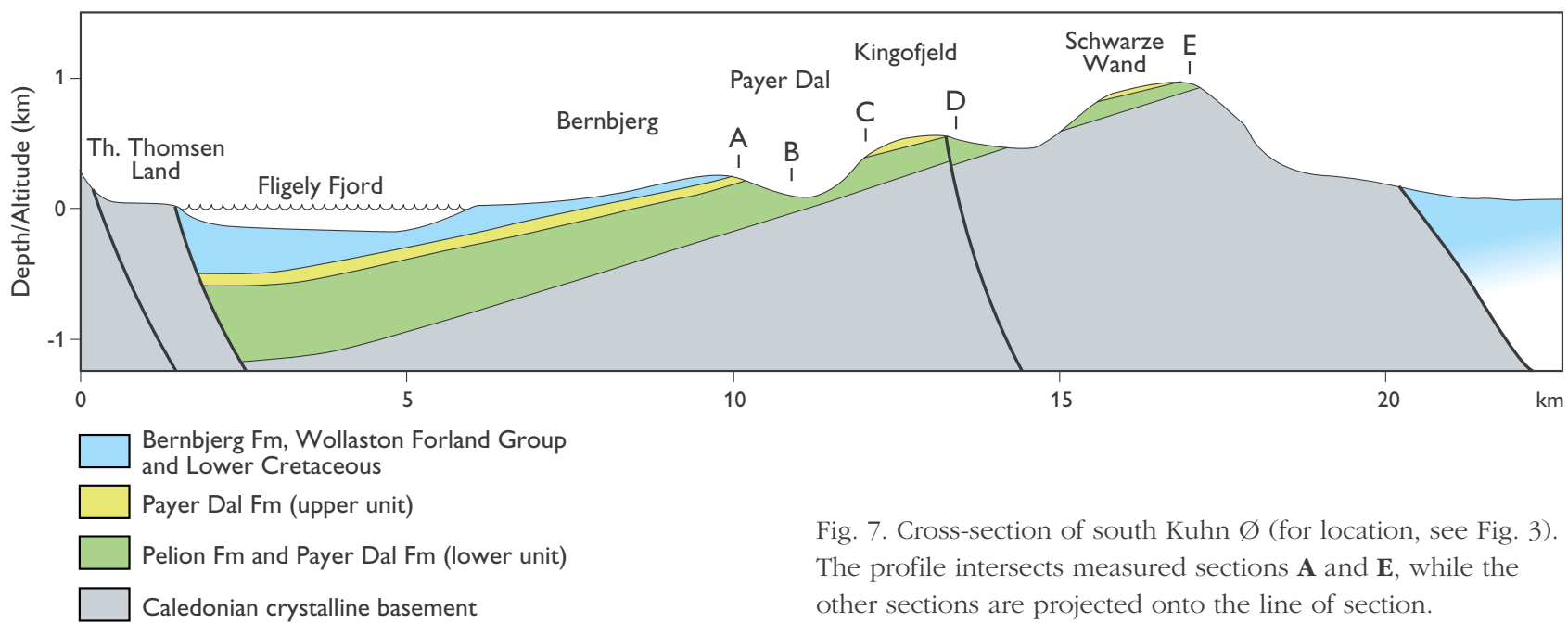



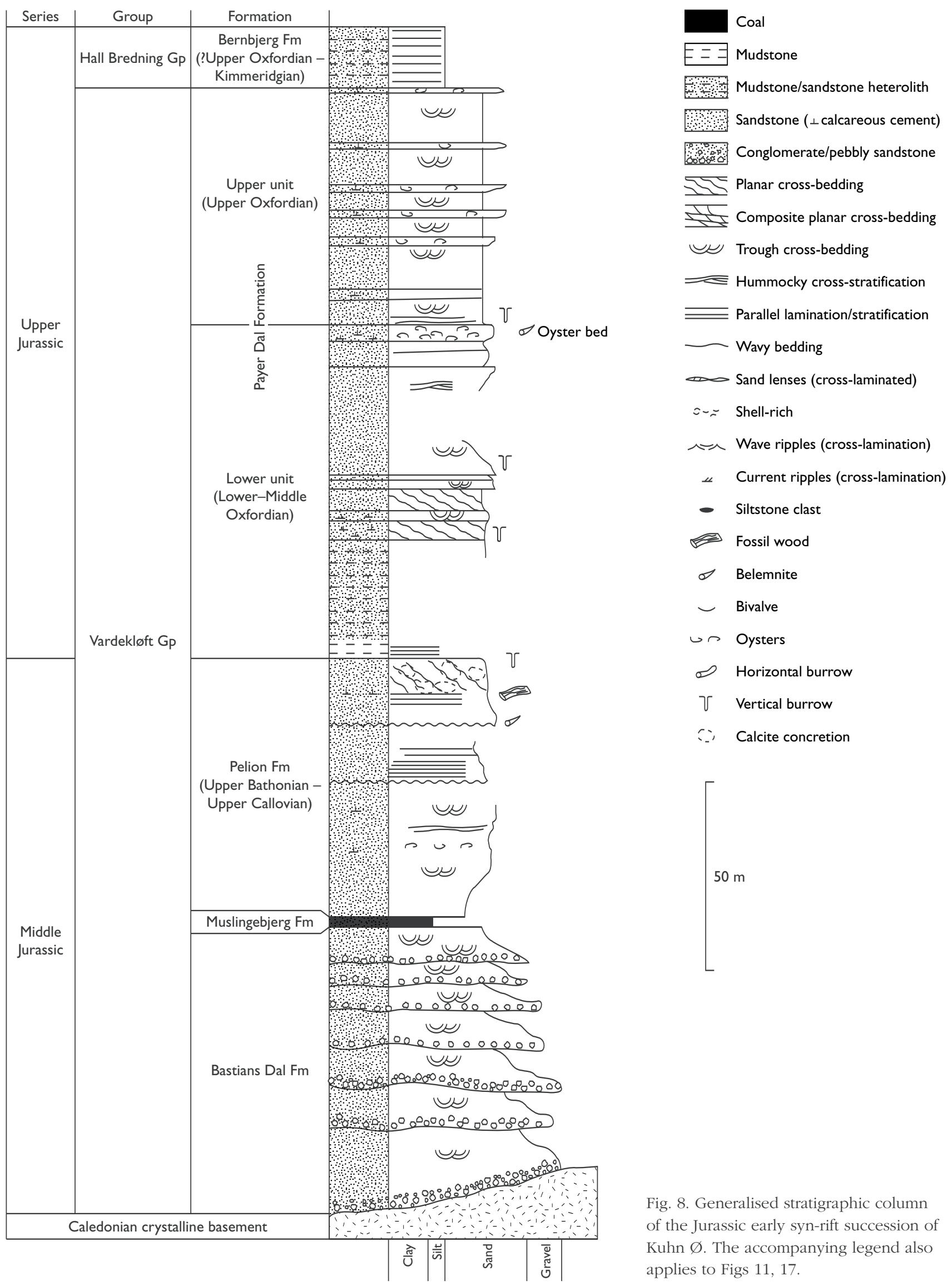

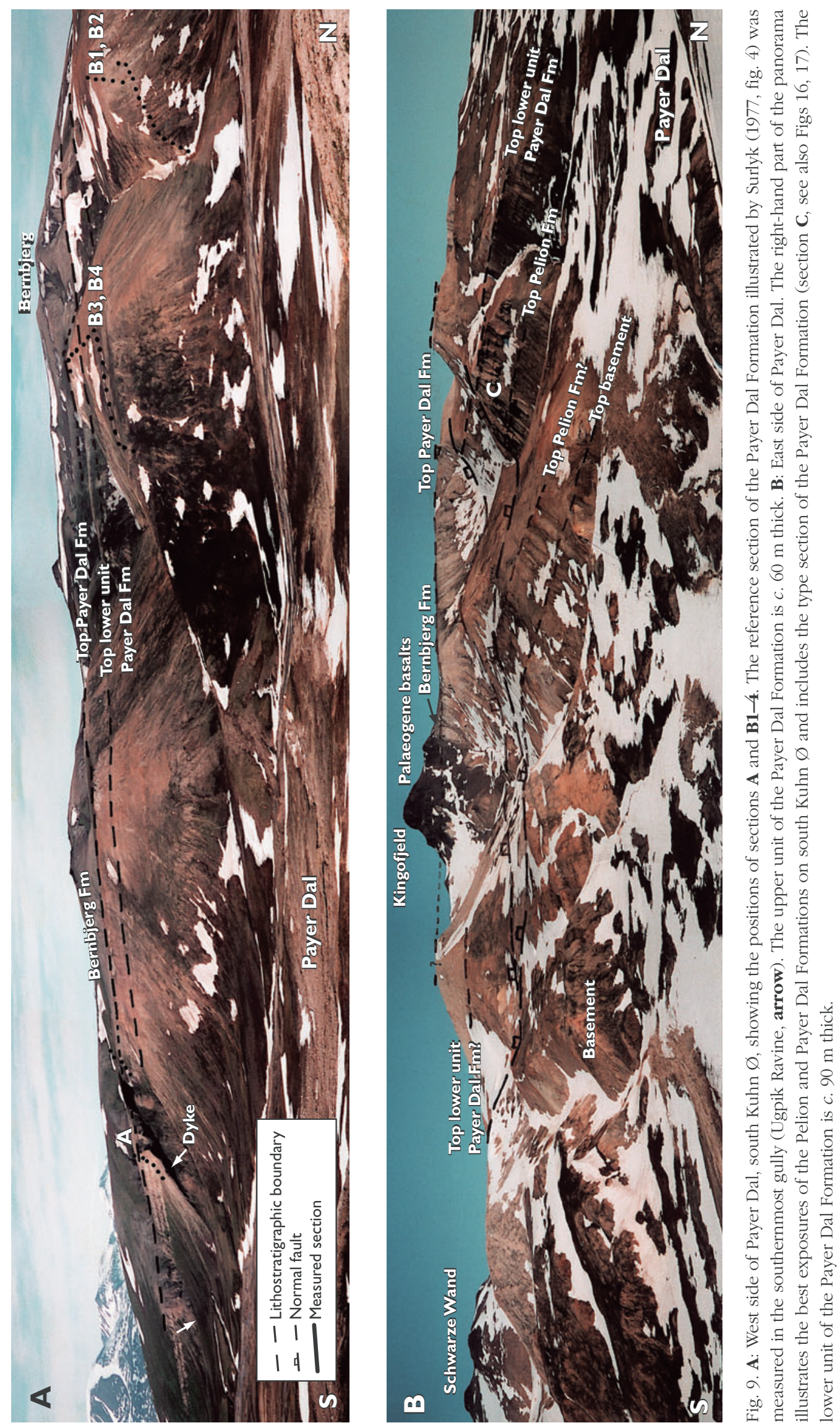

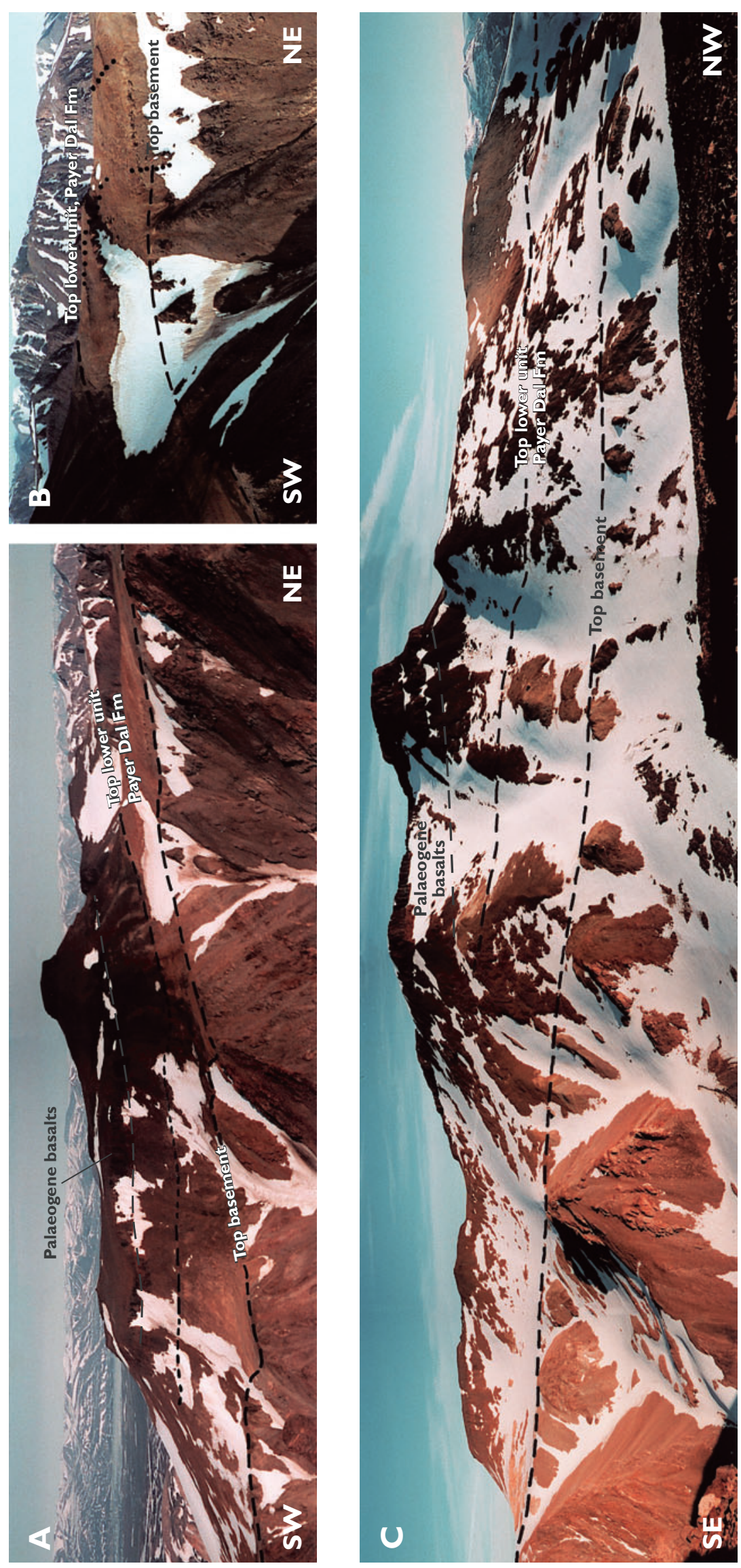

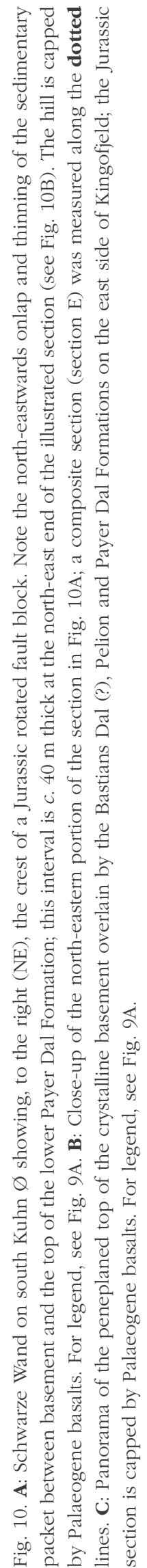


Table 1. Biostratigraphic data, Jurassic - Lower Cretaceous of Kuhn $\varnothing$

\begin{tabular}{|c|c|c|c|}
\hline Formation & Age & Sample* & $\begin{array}{l}\text { Diagnostic flora/fauna - mainly dinocysts, together } \\
\text { with pollen }(P) \text {, ammonites }(A) \text {, foraminifers }(F)\end{array}$ \\
\hline & Early-Middle Barremian & C-57 & $\begin{array}{l}\text { Pseudoceratium anaphrissum, Muderongia australis, } \\
\text { Pseudoceratium pelliferum, Muderongia staurota, Muderongia } \\
\text { testudinaria }\end{array}$ \\
\hline & Early-Middle Barremian & C-58 & P. anaphrissum, Batioladinium longicornutum \\
\hline Bernbjerg & Late Callovian - Oxfordian & C-22 & Scriniodinium crystallinum \\
\hline Bernbjerg & Middle-Late Jurassic & $\mathrm{C}-23$ & Cerebropollenites mesozoicus (P), Haplophragmoides sp. (F) \\
\hline Bernbjerg & Kimmeridgian & C-24 & Aulacostephanus eudoxus (A) \\
\hline Bernbjerg & Bathonian-Kimmeridgian & C-41, C-42, C-79 & Gonyaulacysta jurassica \\
\hline Bernbjerg & Kimmeridgian-Volgian & C-74 & $\begin{array}{l}\text { Rhynchodiniopsis cladophora, G. jurassica, Oligosphaeridium } \\
\text { pulcherrimum, Ammobaculites sp. (F), Haplophragmoides sp. (F) }\end{array}$ \\
\hline Bernbjerg & Oxfordian-Kimmeridgian & C-77, C-78 & R. cf. R. cladophora \\
\hline Bernbjerg & Kimmeridgian & $\mathrm{C}-80 \mathrm{~A}$ & Aulacostephanus mutabilis (A) \\
\hline Bernbjerg & Kimmeridgian-Volgian & C-87 & $\begin{array}{l}\text { Tubotuberella apatela, ?Atopodinium sp., Sirmiodinium grossii, } \\
\text { Hystrichodinium cf. amphiacanthum. }\end{array}$ \\
\hline Bernbjerg & Volgian & C-88 & $\begin{array}{l}\text { Oligosphaeridium patulum, Scriniodinium sp.A, } \\
\text { Cribroperidinium sp. of the perforans/cauda group }\end{array}$ \\
\hline Bernbjerg & $\begin{array}{l}\text { Late Callovian - Oxfordian, } \\
\text { probably Late Oxfordian }\end{array}$ & 037, sect. D4 & $\begin{array}{l}\text { Escarisphaeridum sp. hyalina, Sentusidinium pelionense, } \\
\text { Sirmiodinium grossii, G. jurassica }\end{array}$ \\
\hline Bernbjerg & Kimmeridgian & 157 & $\begin{array}{l}\text { Oligosphaeridium patulum, Ellipsoidictyum cinctum, } \\
\text { Mendicodinium groenlandicum, C. mesozoicus (P) }\end{array}$ \\
\hline Bernbjerg & Kimmeridgian & A4 sect. D4 & Amoeboceras sp. baylei (A) \\
\hline Bernbjerg & Kimmeridgian & $65 \mathrm{~m}$ below $\mathrm{C}-87$ & Amoeboceras subkitchini Spath (A) \\
\hline Payer Dal (upper unit) & Middle-Late Jurassic & C-15, C-49 & C. mesozoicus (P) \\
\hline Pelion/Payer Dal (lower unit) & Oxfordian & $C-3 P$ & G. jurassica, M. groenlandicum, Rigaudella aemula \\
\hline Pelion/Payer Dal (lower unit) & Middle-Late Jurassic & $C-10, C-11, C-21$ & C. mesozoicus (P) \\
\hline Pelion/Payer Dal (lower unit) & Callovian-Oxfordian & C-13 & Sentusidinium rioultii, Rhynchodiniopsis cf. cladophora \\
\hline Payer Dal (lower unit) & $\begin{array}{l}\text { Late Callovian - } \\
\text { Middle Oxfordian }\end{array}$ & C-38 & $\begin{array}{l}\text { Liesbergia scarburghensis, G. jurassica, ?Surculosphaeridium } \\
\text { vestitum, R. cladophora }\end{array}$ \\
\hline Pelion/Payer Dal (lower unit) & $\begin{array}{l}\text { Late Callovian - } \\
\text { Middle Oxfordian }\end{array}$ & C-46 & L. scarburghensis \\
\hline Pelion/Payer Dal (lower unit) & Callovian & C-47 & Pareodinia prolongata \\
\hline Pelion/Payer Dal (lower unit) & $\begin{array}{l}\text { Late Bathonian - } \\
\text { Late Callovian }\end{array}$ & C-54 & $\begin{array}{l}\text { Batiacasphaera dictydia, Sirmiodinium grossii, G. jurassica, } \\
\text { G. pectinigera, Escharisphaeridia sp., molluscs, brachiopods }\end{array}$ \\
\hline Pelion/Payer Dal (lower unit) & ?Callovian & C-59 & Chytroeisphaeridia chytroeides \\
\hline Pelion/Payer Dal (lower unit) & Middle-Late Jurassic & 043 & C. mesozoicus (P), ?Rhynchodiniopsis cladophora \\
\hline Payer Dal & ?Callovian & C-66 & C. chytroeides \\
\hline Pelion & Middle-Late Jurassic & C-85 & C. mesozoicus (P) \\
\hline Bastians Dal & Middle-Late Jurassic & C-19, C-68, C-69 & C. mesozoicus $(\mathrm{P})$ \\
\hline
\end{tabular}

* Location of samples shown on Figures 3-5, 11, 17.

area, south-western Wollaston Forland (Table 2; M. Engkilde, personal communication 1997). The ${ }^{87} \mathrm{Sr} /{ }^{86} \mathrm{Sr}$ isotope values were used for correlating the Jurassic succession between the two areas and with the strontium isotope curves constructed for the Jurassic Period for the United Kingdom (Jones et al. 1994) and East Greenland (M. Engkilde, personal communication 1997). 
Table 2. Strontium isotopic data, Wollaston Forland and Kuhn $\varnothing$

\begin{tabular}{clccccccc}
\hline Section* & Formation & Level* $(\mathrm{m})^{*}$ & $\mathrm{Fe}(\mathrm{ppm})$ & $\mathrm{Mg}(\mathrm{ppm})$ & $\mathrm{Mn}(\mathrm{ppm})$ & $\mathrm{Sr}(\mathrm{ppm})$ & ${ }^{87} \mathrm{Sr}^{86} \mathrm{Sr}^{\frac{1}{*}}$ & $\mathrm{Age}^{\delta}$ \\
\hline 1 & Pelion & 50 & 38 & 1275 & 10 & 850 & 0.706856 & (Middle)-Late Callovian \\
1 & Jakobsstigen & 130 & 75 & 850 & 55 & 816 & 0.706823 & Early-Middle Oxfordian \\
1 & Bernbjerg & 195 & 382 & 1350 & 70 & 924 & 0.706890 & Late Oxfordian \\
1 & Bernbjerg & 215 & 40 & 1000 & 23 & 999 & 0.706876 & Late Oxfordian \\
1 & Bernbjerg & 230 & 10275 & 1000 & 100 & 663 & 0.706881 & Late Oxfordian \\
2 & Pelion & 107 & 30 & 1250 & 40 & 974 & 0.706850 & (Middle)-Late Callovian \\
2 & Bernbjerg & 284 & 70 & 1175 & 18 & 930 & 0.706917 & Latest Oxfordian - \\
& & & & & & & & Early Kimmeridgian \\
\hline
\end{tabular}

* See Fig. 23.

\% The uncertainty of the ${ }^{87} \mathrm{Sr} /{ }^{86} \mathrm{Sr}$ isotope ratio is $\pm 1 \times 10^{-5}$.

$\S$ Relative ages were obtained by comparing isotope values with strontium isotope curve of Jones et al. (1994; M. Engkilde, personal communication 1997).

\section{Stratigraphy and sedimentology}

The Jurassic succession on Kuhn $\varnothing$ is subdivided into five formations, the Bastians Dal (new), Muslingebjerg, Pelion (redefined), Payer Dal (new) and Bernbjerg Formations (Fig. 2). The first four formations occur within the Vardekløft Group whereas the Bernbjerg Formation is referred to the Hall Bredning Group (Fig. 2). The new and redefined formations are described formally below, together with a brief account of the characteristic features of the Muslingebjerg and Bernbjerg Formations on Kuhn $\varnothing$. It should be noted that the revised lithostratigraphic scheme presented in Figure 2 and in Surlyk (2003, this volume, fig. 5) must be considered as provisional, pending publication. In this paper, this relates especially to the Muslingebjerg and Pelion Formations which are described here from Kuhn $\varnothing$, as these units are elevated in status from member to formation in the revised scheme.

\section{Bastians Dal Formation}

new formation

History. A unit of cobble conglomerates, $5 \mathrm{~m}$ thick, at the base of the Pelion Formation and directly overlying crystalline basement was described from one locality on the mountain of Kingofjeld, eastern Payer Dal by Maync (1947, p. 15). This unit is included in the new Bastians Dal Formation which is erected here for a succession of mainly conglomerates and pebbly sandstones forming the basal unit of the Jurassic succession on Kuhn $\varnothing$. The type area of the formation was mapped by Vischer (1943, p. 42-43) but rocks belonging to the new Bastians Dal Formation were not recognised, probably due to deep snow cover (A. Vischer in: Koch 1955, p. 562-564).

Name. After the NW-SE-trending valley of Bastians Dal, in western central Kuhn $\varnothing$ (Figs 3, 5; Vischer 1943 , plate 1).

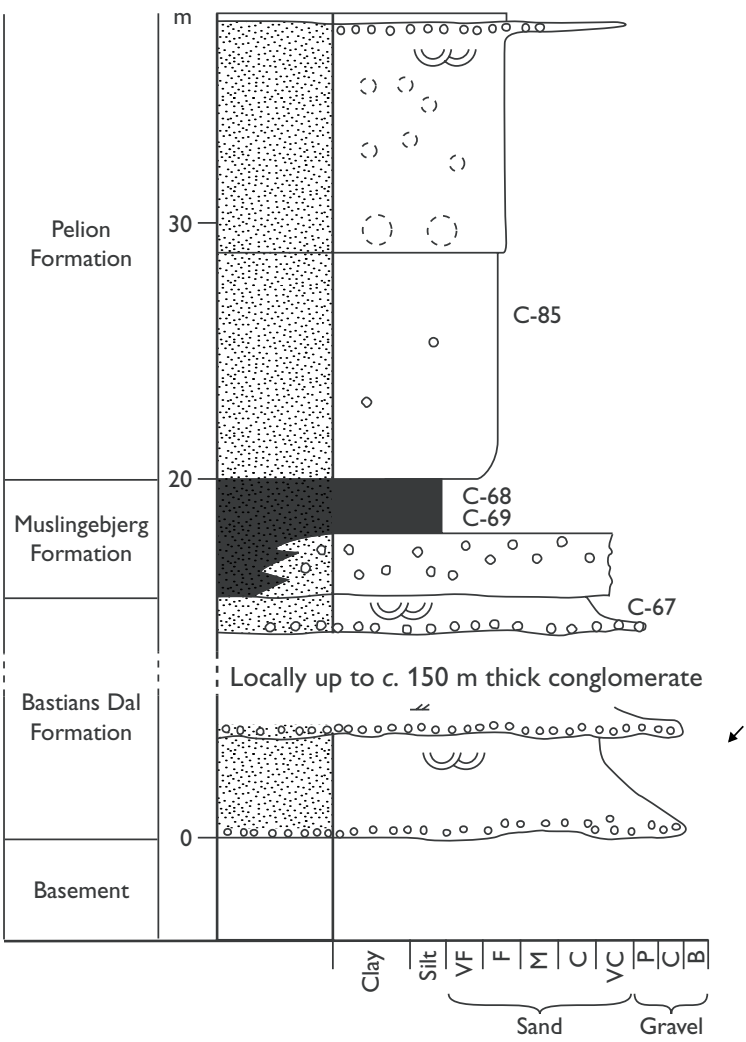

Fig. 11. Stratigraphic log of the Bastians Dal succession, including the type section of the Bastians Dal Formation. The uppermost part of the Pelion Formation is not shown. For legend, see Fig. 8; C-67, sample number. 


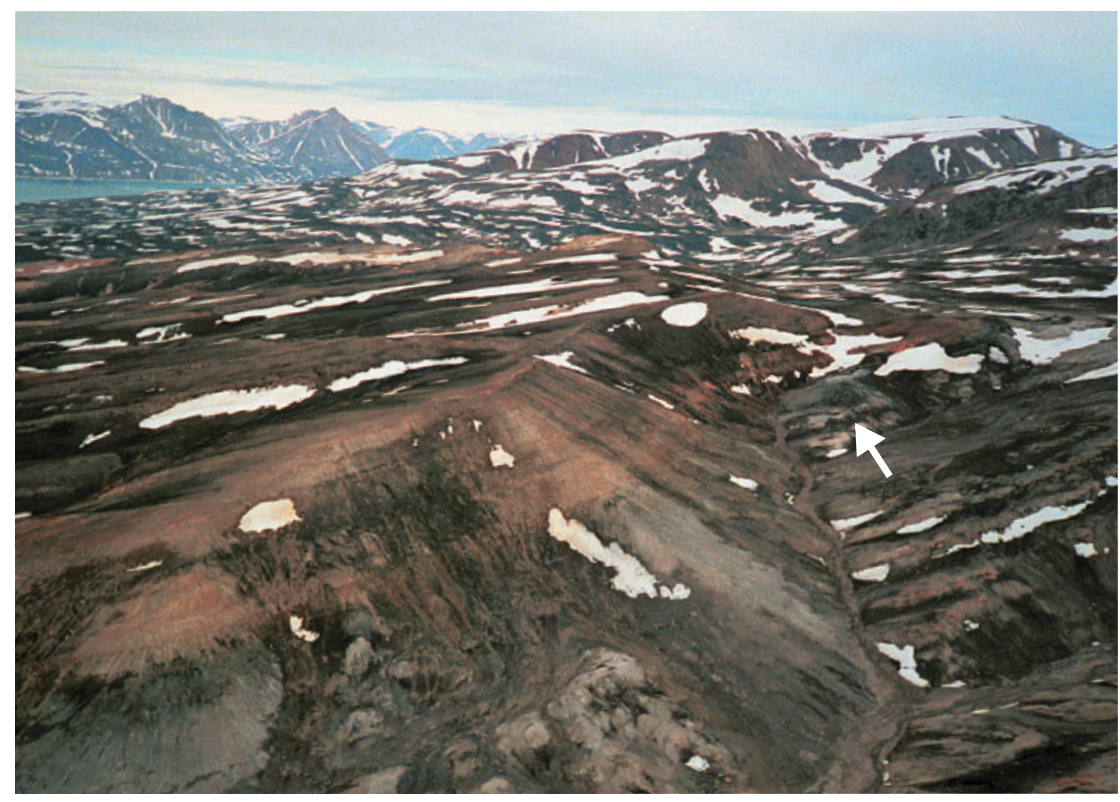

Fig. 12. Grey fluvial conglomerates of the Bastians Dal Formation overlain by light brown shallow marine sandstones of the Pelion Formation (c. $20 \mathrm{~m}$ thick Pelion Formation section crops out along the ridge, centre foreground). Bastians Dal, central Kuhn $\varnothing$, viewed towards the north with Th. Thomsen Land in the background. Arrow indicates location of exposed conglomerates illustrated in Fig. 13.

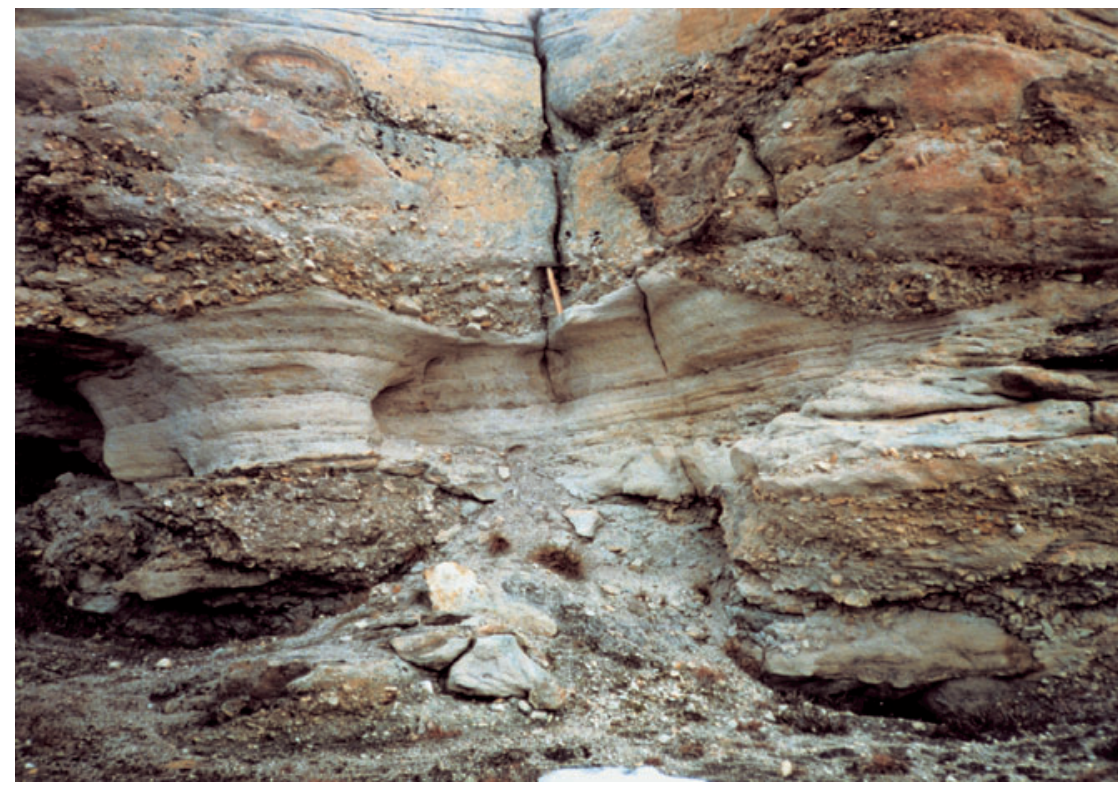

Fig. 13. Stacked fining-upwards conglomeratic units with cut and fill structures, typical of the Bastians Dal Formation. Hammer, $30 \mathrm{~cm}$ long, for scale. For location, see Fig. 12.

Type locality and type section. The east side of Bastians $\mathrm{Dal}$, where the type section is located (Figs 5, 11).

Thickness. Maximum thickness of 100-150 m in Bastians Dal, estimated from photographs and measured sections; the formation thins rapidly towards the south within the Bastians Dal area and is only $1-5 \mathrm{~m}$ thick on southern Kuhn $\varnothing$ (Maync 1947).

Lithology. The Bastians Dal Formation consists of quartz pebble conglomerates and pebbly sandstones. The formation has a distinctive grey weathering colour, due to a high content of carbonaceous material and coal lenses, and contrasts with the light brown weathering colour of the Pelion Formation above (Fig.12).

Boundaries. The formation rests directly on crystalline basement rocks on Kuhn $\varnothing$. The upper boundary is placed where the conglomerates and pebbly sandstones of the Bastians Dal Formation are overlain by coals of the Muslingebjerg Formation or, where the Muslingebjerg Formation is not developed, by fine- to medium-grained sandstones of the Pelion Formation.

Distribution. The formation overlies crystalline basement in central and southern Kuhn $\varnothing$. In Bastians Dal, the 

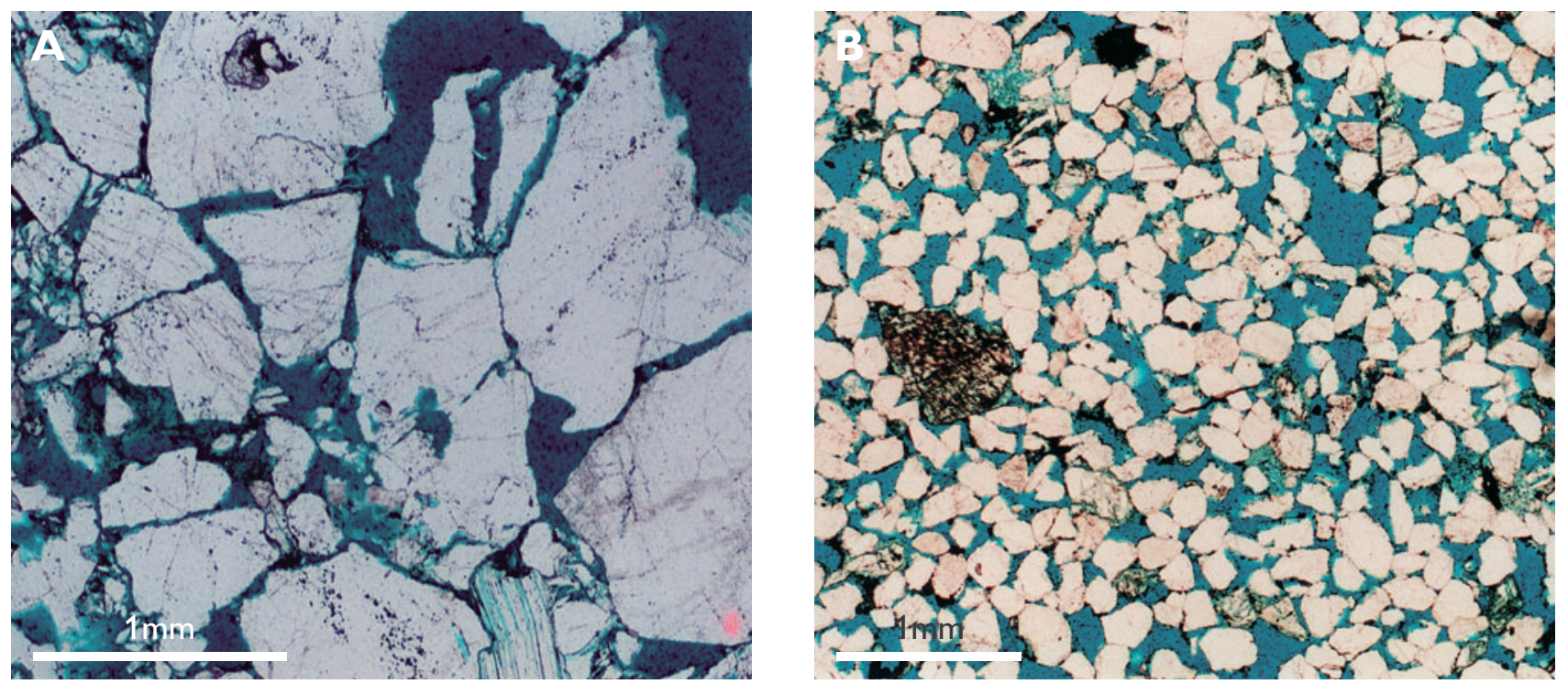

Fig. 14. Thin-section photographs in plane-polarised light. A: Sandstone from the uppermost Bastians Dal Formation illustrating the poor sorting, angularity and poorly cemented character of the deposits. Sample C-67, Bastians Dal.

B: Weakly cemented sandstone from the Payer Dal Formation (lower unit) with 19\% helium porosity; sample C-60, west Kingofjeld (Fig. 17).

C: Cemented sandstone (cf. Fig. 14B) from the Payer Dal Formation (lower unit); sample C-62, west Kingofjeld (Fig. 17).

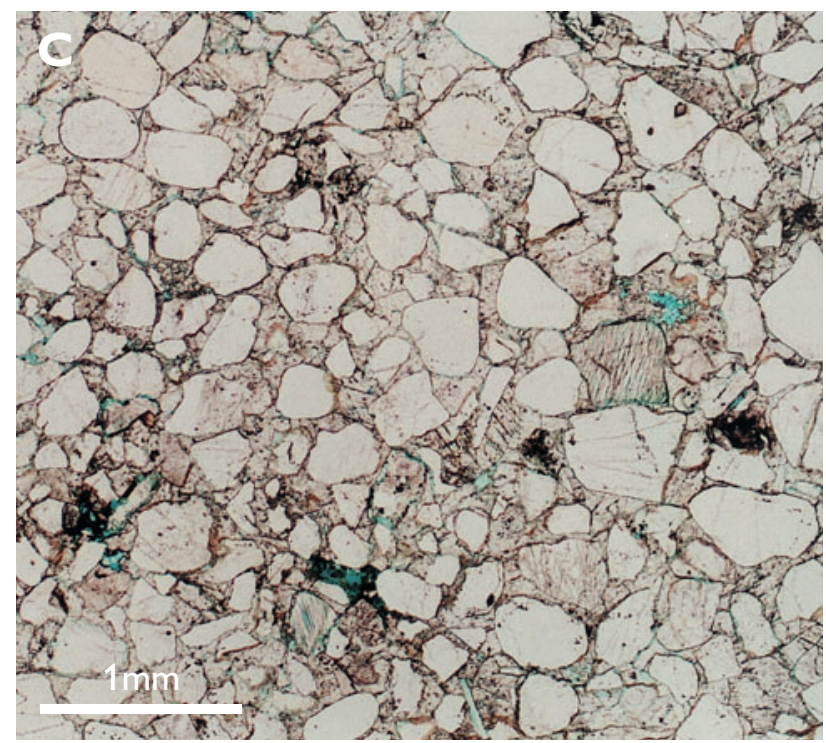

formation seems to fill a valley incised into the crystalline basement whereas in the Payer Dal area, it is thin and locally absent.

Geological age. The Bastians Dal Formation is of general Middle Jurassic age based on the presence of Cerebropollenites mesozoicus pollen within the formation and the occurrence of dinocysts within the overlying Pelion Formation which indicate a Late Bathonian - Late Callovian age (Table 1).

Facies. In Bastians Dal, the formation is characterised by stacked fining-upwards units, $0.1-2 \mathrm{~m}$ thick, consisting of coarse-grained pebble and cobble conglomerates with quartzite clasts overlying a basal erosional surface

followed by trough cross-bedded or parallel-laminated quartz sandstones, commonly rich in mica (Fig. 13). Cobbles are rounded whereas sand grains are angular to subrounded (Fig. 14A). The poor sorting and angularity of the quartz grains suggest that the sediments are immature and close to their source of origin, probably the crystalline basement rocks to the east and north. Microfractures are present in all quartz grains, supporting a metamorphic basement origin. Palaeocurrent directions measured from the trough cross-bedded sandstones are towards the south-west (average $240^{\circ}$ ).

Palaeoenvironment. The carbonaceous, immature conglomerates and pebbly sandstones of the Bastians Dal Formation are interpreted to have been deposited by 

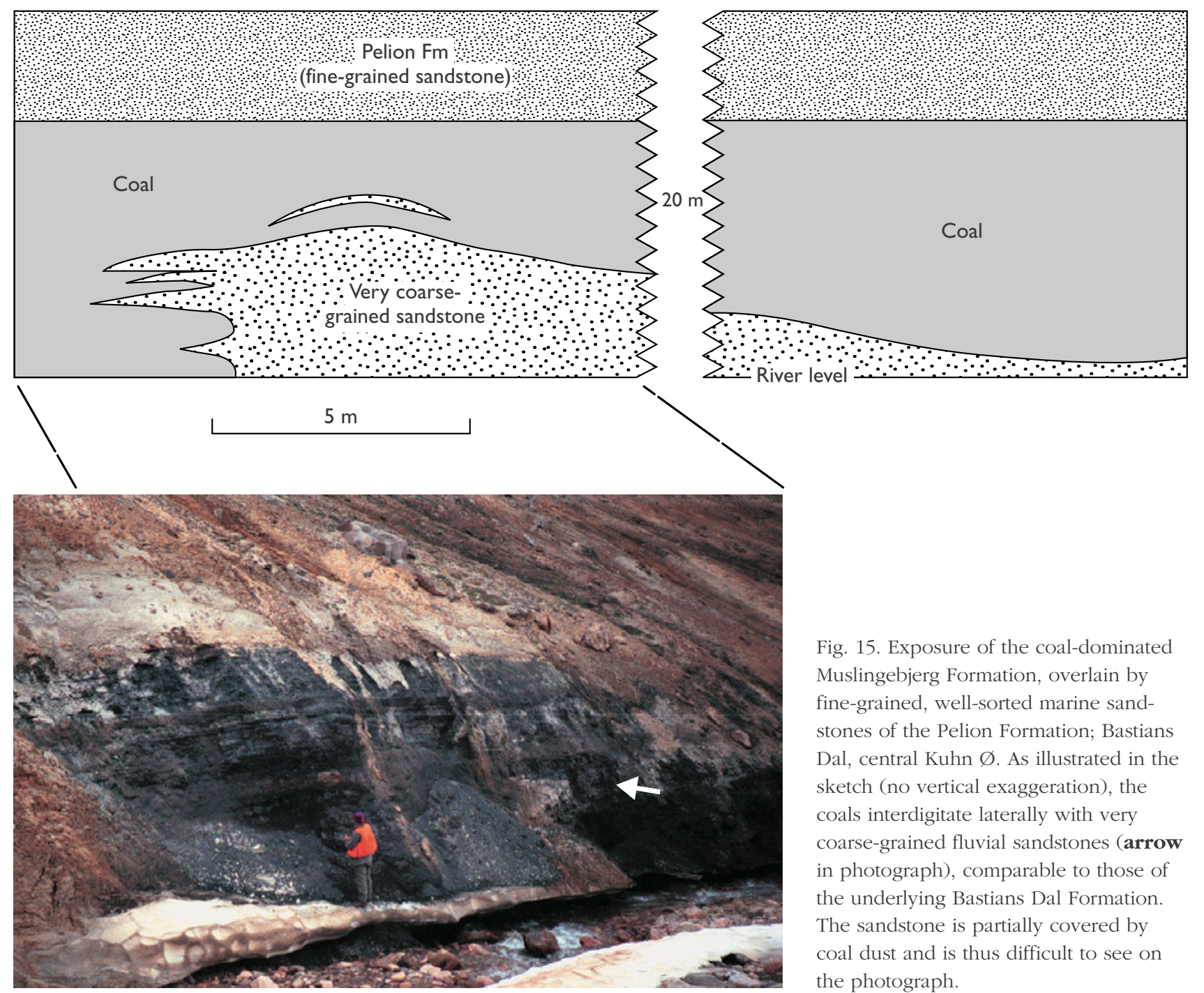

Fig. 15. Exposure of the coal-dominated Muslingebjerg Formation, overlain by fine-grained, well-sorted marine sandstones of the Pelion Formation; Bastians Dal, central Kuhn $\varnothing$. As illustrated in the sketch (no vertical exaggeration), the coals interdigitate laterally with very coarse-grained fluvial sandstones (arrow in photograph), comparable to those of the underlying Bastians Dal Formation. The sandstone is partially covered by coal dust and is thus difficult to see on the photograph.

south-westwards flowing braided rivers. The finingupwards units reflect decreasing energy conditions during deposition and were probably formed by fluvial channel erosion followed by the migration of channel bars towards the south-west within the channels (Cant \& Walker 1976; Miall 1977).

The formation appears to be mainly restricted to the Bastians Dal area (Fig. 3). The overall marked peneplaned nature of the basement surface and the pronounced lateral thinning of the formation suggest that it is restricted to a valley system incised into the basement surface. It is not possible to define the orientation of the axis of the valley or the northwards extent of the formation due to Quaternary cover. Incision is interpreted to have resulted from relative base-level lowering, probably in association with late Early or early Middle Jurassic regional uplift enhanced by the onset of half-graben block rotation in Middle Jurassic time. Incised drainage systems possibly followed zones of weakness in the crystalline basement such as fault zones or less resistant metamorphic facies. During a subsequent rise in base level, a south-west flowing fluvial system filled the valley with sandstones and conglomerates. On southern Kuhn $\varnothing$, the Bastians Dal Formation was apparently deposited on the peneplain marginal to the incised valley system inferred for central Kuhn $\varnothing$.

\section{Muslingebjerg Formation}

Facies. Coal beds overlying the Bastians Dal Formation are referred to the coal-bearing Muslingebjerg Formation. This lithostratigraphic unit was given member status by 


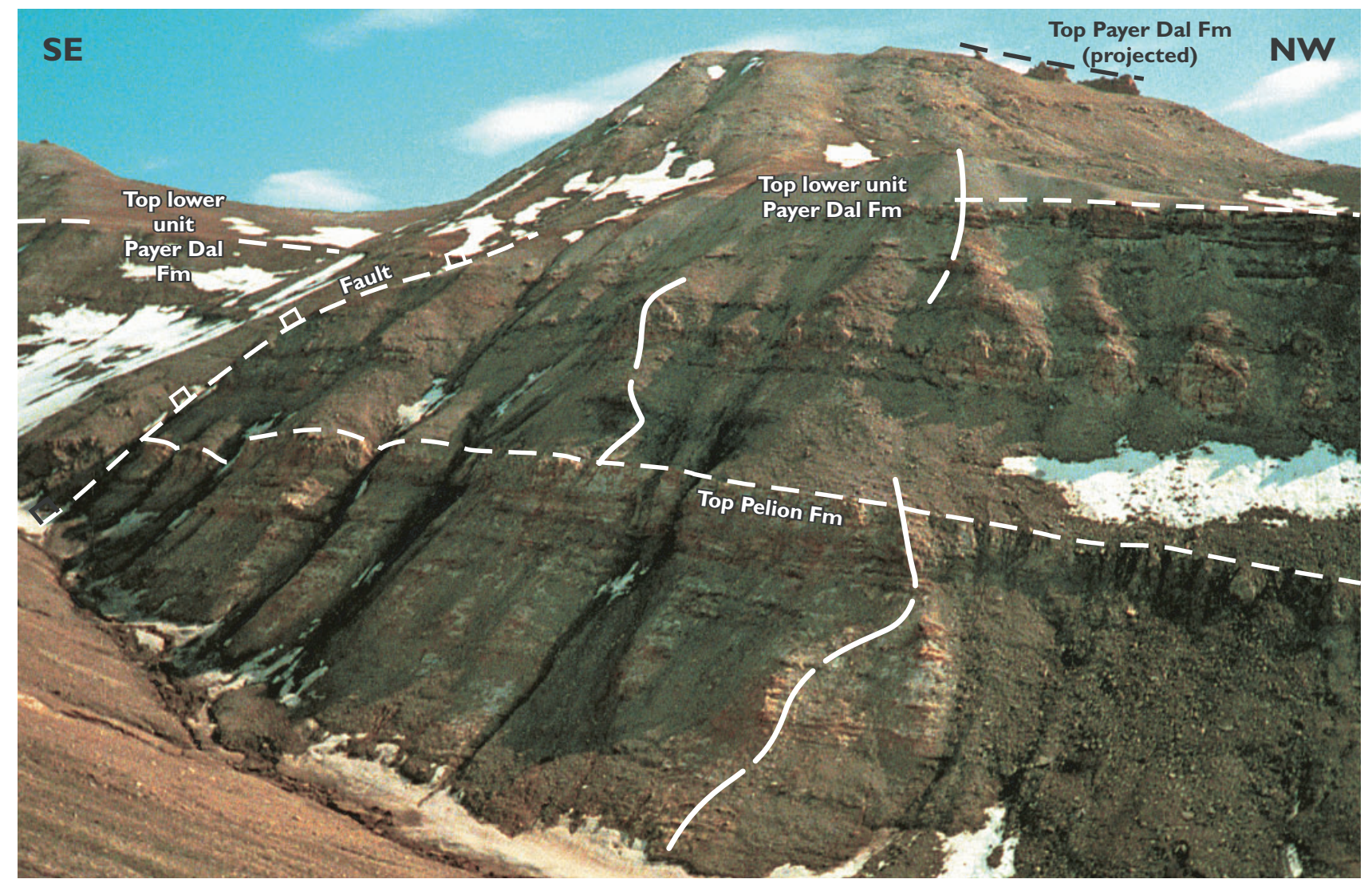

Fig. 16. Type section (section C) of the Payer Dal Formation, west Kingofjeld (see Figs 4, 9B, 17); the line of section is indicated by the dotted lines. The boundary between the Payer Dal Formation and the overlying Bernbjerg Formation is exposed about one kilometre east (left) of this locality (see Fig. 9B). The lower unit of the Payer Dal Formation is c. 90 m thick. For legend, see Fig. 9A

Surlyk (1977) but is upgraded to formation in the revised scheme of Surlyk (2003, this volume, fig. 5). At the type locality at Kulhus in southern Hochstetter Forland, the formation is at least $20 \mathrm{~m}$ thick and consists of coals interbedded with lagoonal siltstones and sandstones and subordinate shoreface sandstones (Clemmensen \& Surlyk 1976; Petersen et al. 1998). In Bastians Dal, the Muslingebjerg Formation is up to $11 \mathrm{~m}$ thick and consists of coals interbedded locally with fluvial deposits comparable to those of the underlying Bastians Dal Formation (Figs 11, 15). In Payer Dal, a coal bed up to $0.15 \mathrm{~m}$ thick overlies weathered crystalline basement or thin fluvial deposits of the Bastians Dal Formation. The coal beds are overlain by fine- to medium-grained sandstones of the Pelion Formation on Kuhn $\varnothing$ and the Payer Dal Formation on Hochstetter Forland. The Muslingebjerg Formation on Kuhn $\varnothing$ is of early Middle Jurassic age based on the occurrence of Middle-Upper Jurassic pollen in the underlying fluvial sediments of the Bastians Dal Formation and Upper Bathonian Upper Callovian dinocysts in the overlying Pelion
Formation (Table 1). Dinocysts immediately above the coals in the type section at Kulhus, Hochstetter Forland, are indicative of the Upper Callovian P. athleta Chronozone (Piasecki \& Stemmerik in press).

Palaeoenvironment. The coal beds of the Muslingebjerg Formation represent lagoonal swamps that formed on a coastal plain during base-level rise. The alternation of coal beds and shoreface deposits at Kulhus demonstrates that the peat-forming mires were repeatedly terminated by marine transgressions (Clemmensen \& Surlyk 1976; Petersen et al. 1998). Interfingering of coals with fluvial deposits in Bastians Dal on Kuhn $\varnothing$ suggests that the coal beds were also confined within the incised valley system within which the fluvial Bastians Dal Formation was deposited. The thin coal beds that directly overlie or occur close to basement in Payer Dal were possibly deposited immediately adjacent to the eastern low-angle margin of the incised valley. As flooding continued, the incised valley and interfluves were drowned and the coal-bearing sediments were abruptly overlain 


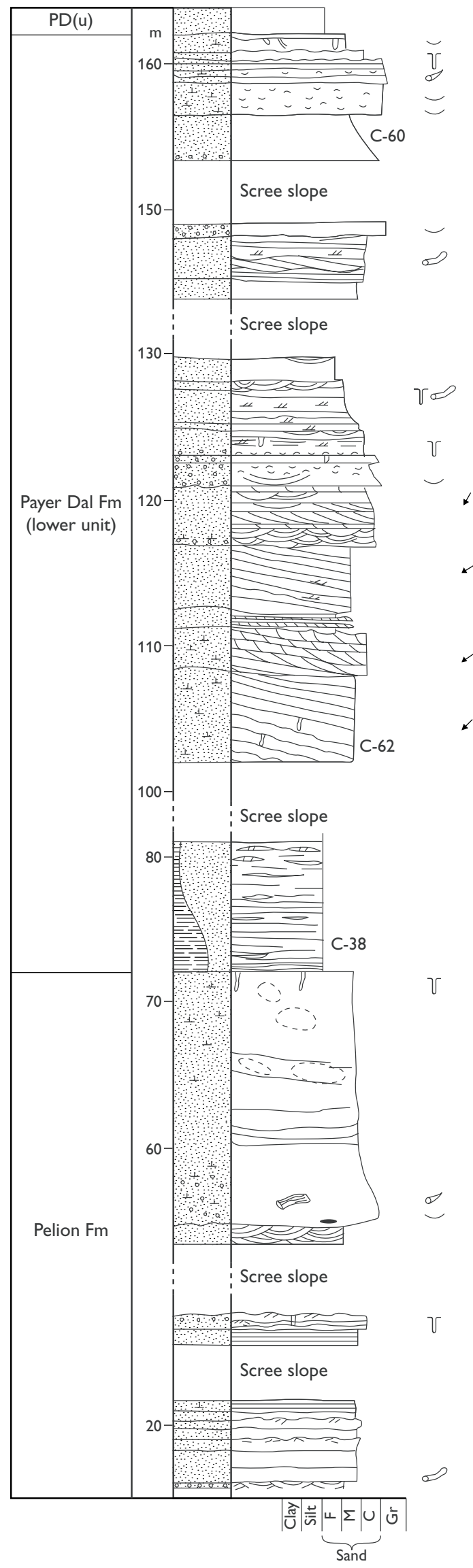

by shallow marine sands of the Pelion or Payer Dal Formations. The Muslingebjerg Formation thus marks the transition from fluvial sedimentation of the Bastians Dal Formation to fully marine sedimentation of the Pelion and Payer Dal Formations.

Geochemistry. Coal samples from Payer Dal have high hydrogen indices (HI) in the range 430-695 $\mathrm{mg} \mathrm{HC/g}$ TOC (mg hydrocarbons/g total organic carbon content) (Fig. 4; samples C-6, -8, -19, -20). Values of $T_{\max }$ are in the range $429-432^{\circ} \mathrm{C}$, and TOC values are $51-59 \%$. A coal sample from central Kuhn $\varnothing$ (Fig. 5, C-68) gave a $\mathrm{HI}$ value of only $170 \mathrm{mg} \mathrm{HC/g}$ TOC. The coals are relatively 'liptinitic', corresponding to kerogen types II-III. The organic matter is dominantly derived from land plants, and has a good potential for generation of probably waxy oil. The coals of Hochstetter Forland are also potential oil-prone source rocks (Bojesen-Koefoed et al. 1996; Petersen et al. 1998).

\section{Pelion Formation}

redefined

History. The shallow marine sandstones on Kuhn $\varnothing$ that overlie crystalline basement or in some areas succeed the Bastians Dal or Muslingebjerg Formations were previously all included in the Pelion Member (Surlyk 1977); this lithostratigraphic unit is promoted to the rank of formation in the revised lithostratigraphic scheme (Surlyk 2003, this volume, fig. 5). The sandstones are here subdivided into the Pelion Formation (below) and the new Payer Dal Formation (above) which are separated by a major drowning surface expressed as a sharp boundary between mainly medium-grained sandstones and the overlying siltstones, heteroliths and fine-grained sandstones. The description presented here only covers the occurrence on Kuhn $\varnothing$.

Thickness. About 120 m in Payer Dal.

Lithology. The Pelion Formation consists of yellowish, moderately to well-sorted, fine- to coarse-grained quartz sandstone.

Fig. 17. Section $\mathbf{C}$ through the Pelion - lower Payer Dal Formations, west Kingofjeld, including the type section of the Payer Dal Formation (Figs 9B, 16). For legend, see Fig. 8. PD (u), Payer Dal Formation, upper unit; C-38, sample number. 


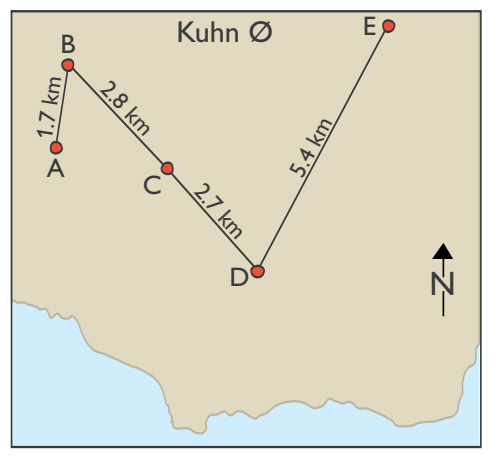

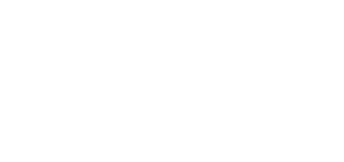

Fornbjerg

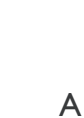

A

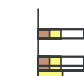

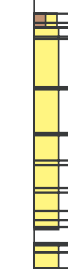

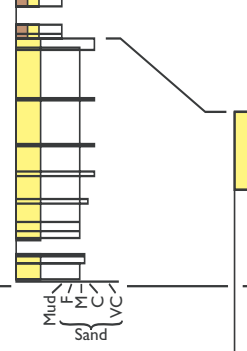

100

B

C
Payer Dal

Formation

(upper unit)

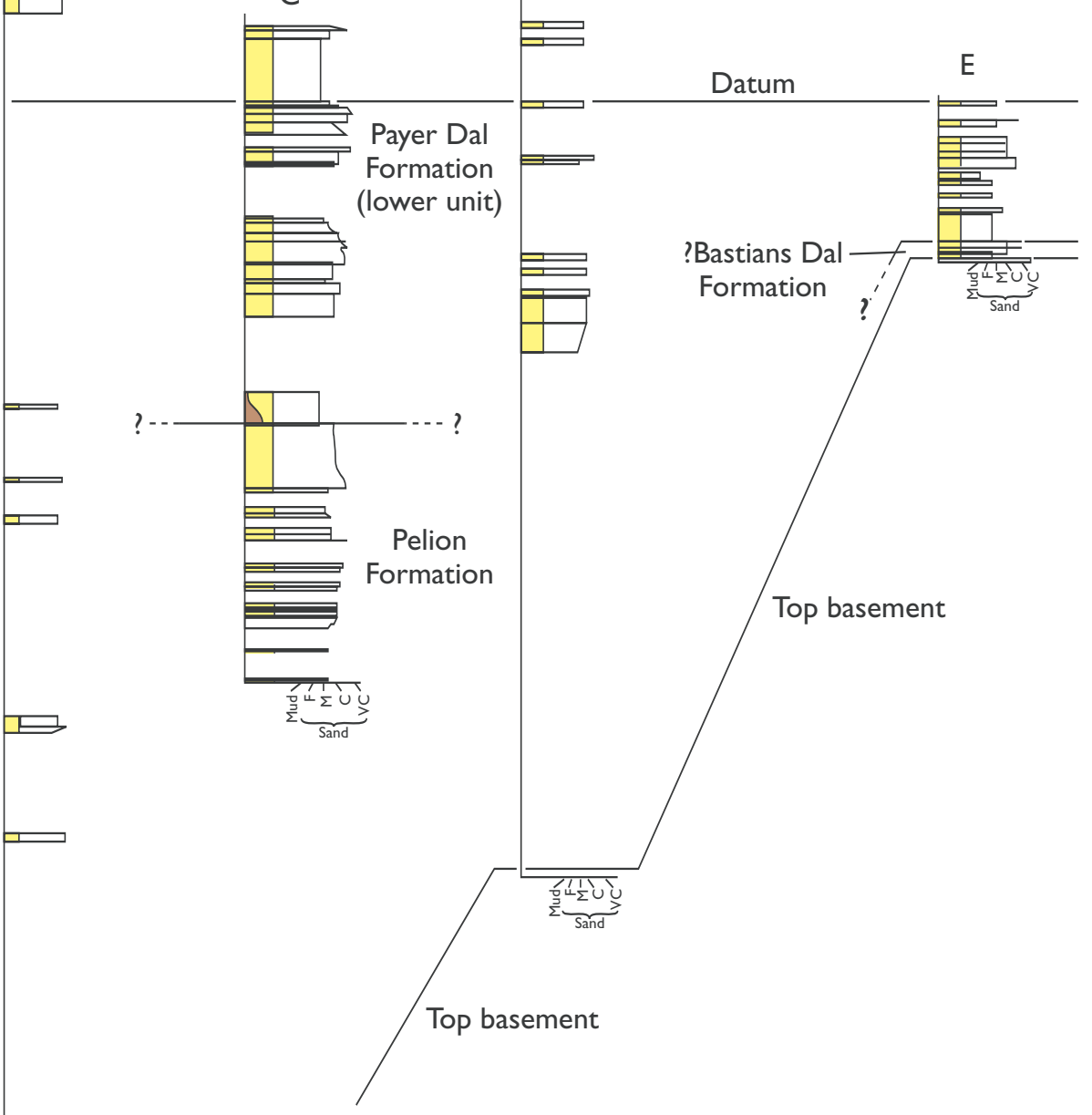

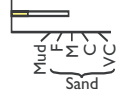




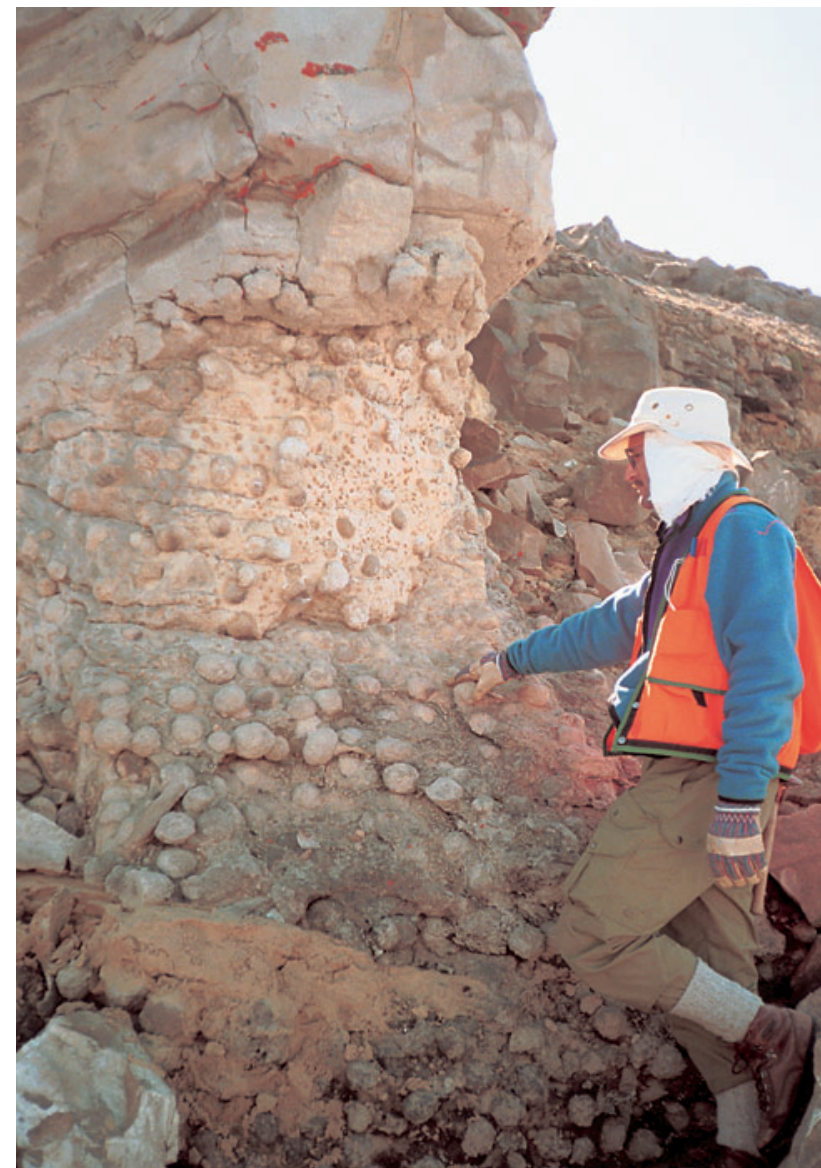

Fig. 19. Calcite concretions in the Pelion Formation or the lower Payer Dal Formation. Bastians Dal, central Kuhn $\varnothing$.

Boundaries. Overlies crystalline basement or pebbly fluvial sandstones of the Bastians Dal Formation, and the coal-bearing Muslingebjerg Formation in southern and central Kuhn $\varnothing$. The upper boundary is sharp and separates Pelion Formation sandstones from siltstones and heteroliths of the overlying Payer Dal Formation. It can be correlated with a similar surface at the top of the Pelion Formation in Cardiocerasdal, Wollaston Forland, and can possibly be traced as far south as Jameson Land. The Pelion Formation and the lower unit of the Payer Dal Formation cannot be clearly separated in Bastians Dal, central Kuhn $\varnothing$.

Distribution. The Pelion Formation is persistent throughout the Jurassic outcrop on Kuhn $\varnothing$ and regionally is recognised from Store Koldewey in the north (Piasecki et al. in press) to Jameson Land in the south (Fig. 1).

Geological age. The formation is poorly dated on Kuhn $\varnothing$ due to a lack of ammonites. However, a Late
Bathonian ammonite fauna in the basal part of the formation was reported from nearby Wollaston Forland by Maync (1947). Dinocyst assemblages suggest a Late Bathonian - Late Callovian age on Kuhn $\varnothing$ (Table 1). Strontium isotope analysis $\left({ }^{87} \mathrm{Sr} /{ }^{86} \mathrm{Sr}\right)$ of a belemnite from the uppermost part of the formation suggests a Late or possibly Middle Callovian age, by comparison with the strontium isotope curve of Jones et al. (1994; M. Engkilde, personal communication 1997).

Facies. The formation consists mainly of moderately well-sorted quartz sandstones with subangular to subrounded grains. Ammonites are very rare, whereas belemnites and bivalves are abundant at certain levels. Faunal assemblages are generally of low diversity and high density probably indicating a high-stress marine environment with fluctuating salinities (Surlyk 1977). In the Payer Dal area, the Pelion Formation is best exposed in section C, west Kingofjeld, where it is about $120 \mathrm{~m}$ thick (Figs 4, 9B, 16-18). The formation is dominated by evenly laminated, swaley cross-stratified, and intensely bioturbated, fine- to medium-grained sandstones alternating with wave rippled or trough cross-bedded, medium- to coarse-grained sandstones. Structureless pebbly sandstone lags with erosional lower boundaries, sometimes rich in bivalve shells, are present locally. A calcite-cemented, bench-forming sandstone (c. $15 \mathrm{~m}$ thick), which seems to be of regional extent on Kuhn $\varnothing$, forms the top of the formation and is capped by the marked flooding surface (see above).

In the more proximal setting in Bastians Dal, the Pelion and Payer Dal Formations are partially covered by scree and it has not been possible to recognise the surface separating the two formations. Shallow marine sandstones probably occur both below and above the drowning surface and good outcrops are required in order to differentiate the two formations.

The lower $45 \mathrm{~m}$ of the Pelion Formation in Bastians Dal consist of well-sorted, very fine- to fine-grained sandstones with numerous thin carbonaceous laminae. Layers of pebbles and poorly sorted beds ranging in grain size from fine sand to cobbles occur locally. Only few sedimentary structures and bedding planes can be observed due to weathering and scree cover, with the exception of small-scale trough cross-beds and, towards the top, localised herringbone cross-bedding.

This basal unit is probably overlain by a sandstone succession, estimated to be $c .35 \mathrm{~m}$ thick, which is exposed further to the west. Correlation is uncertain, however, due to the intervention of an inferred NNW-SSEtrending fault. The succession consists of four prominent 
exposed sections, each $c .3-8 \mathrm{~m}$ thick, that comprise light brown, concretionary sandstones overlain by light grey, calcite-cemented sandstones; these benches are separated by poorly exposed, scree-covered intervals of similar thickness. The concretionary sandstones display characteristic 'cannon ball' concretions which litter the slopes below (Fig. 19). The concretions, which range from a few centimetres to $30 \mathrm{~cm}$ in diameter (average $10 \mathrm{~cm}$ ), commonly obscure sedimentary structures. The calcite-cemented sandstone intervals show trough crossbedding and are typically capped by structureless or parallel-laminated beds. The upper part of the formation is poorly exposed in this area.

Palaeoenvironment. Onset of deposition of the Pelion Formation records regional marine flooding of the crystalline basement peneplain or the sediments of the Bastians Dal and Muslingebjerg Formations. Deposition took place in the lower to upper shoreface based on the dominance of evenly laminated, swaley cross-stratified, and intensely bioturbated fine- to medium-grained sandstones alternating with wave rippled or trough cross-bedded, medium- to coarse-grained sandstones. The pebbly sandstone lags with erosional lower boundaries which occur locally in the formation are interpreted as transgressive lags, formed by wave winnowing of underlying upper shoreface and foreshore deposits. A detailed account of the sedimentology and sequence stratigraphy of the Pelion Formation further south in Jameson Land is given by Engkilde \& Surlyk (2003, this volume).

\section{Payer Dal Formation}

new formation

History. The rocks of this new formation were first recognised by Maync (1947) who included them in the upper part of his Yellow Series. They form the upper part of the Pelion Member of Surlyk (1977).

Name. After the valley of Payer Dal in southern Kuhn $\varnothing$ (Figs 4, 9).

Type locality and type section. The eastern side of Payer Dal; the type section (section C) is located on the west flank of Kingofjeld (Figs 4, 9B, 16, 17).

Reference section. Ugpik Ravine, west Payer Dal (Fig. 9A; Surlyk 1977, fig. 4).
Thickness. In Payer Dal, the formation is about $150 \mathrm{~m}$ thick. The thickness of the formation in Bastians Dal is unknown due to difficulties in defining the base of the formation in poor exposure.

Lithology. Fine- to coarse-grained cross-bedded or structureless, light coloured, mainly yellowish quartz sandstone. Pebbly sandstone lags commonly rich in marine bivalves and belemnites occur locally. Siltstones and heteroliths form the basal part of the formation in Payer Dal.

Boundaries. In Payer Dal, the lower boundary is a distinct surface separating the carbonate-cemented sandstone unit of the uppermost Pelion Formation from the siltstones and heteroliths of the basal Payer Dal Formation. The upper boundary is placed where sandstones of the Payer Dal Formation are sharply overlain by offshore siltstones and heteroliths of the Bernbjerg Formation.

Distribution. The formation occurs on Kuhn $\varnothing$, Store Koldewey, Hochstetter Forland and Hold with Hope (Piasecki et al. in press; Vosgerau et al. in press).

Geological age. The age of the formation is not wellconstrained due to a lack of ammonites. Dinocyst assemblages suggest a mainly Early - early Late Oxfordian age (Table 1).

Subdivision. The formation is subdivided into a lower coarsening-upwards siltstone-sandstone unit and an upper sandstone-dominated unit. These two units are separated by a succession of pebbly sandstones, up to $3 \mathrm{~m}$ thick, and are considered informal members.

Facies. In Payer Dal, the basal part of the lower Payer Dal Formation consists of a succession of siltstones and heteroliths which has a minimum lateral extent of a few hundred metres but cannot be traced further due to extensive scree cover (Figs 16, 17). These basal sediments coarsen upwards into cross-bedded, mediumto coarse-grained sandstones which alternate with evenly laminated, fine- to medium-grained sandstones or wave rippled, medium-grained sandstones (Fig. 17). The sets of the cross-bedded sandstones are up to $2 \mathrm{~m}$ thick. The sandy foresets are commonly separated by single and double mud drapes. Foreset dip azimuths are mainly towards the south-west, but bi-directionally orientated foresets also occur. A pebbly sandstone interval, up to $3 \mathrm{~m}$ thick, containing abundant thick-shelled bivalves and belemnites locally forms the top of the unit. 


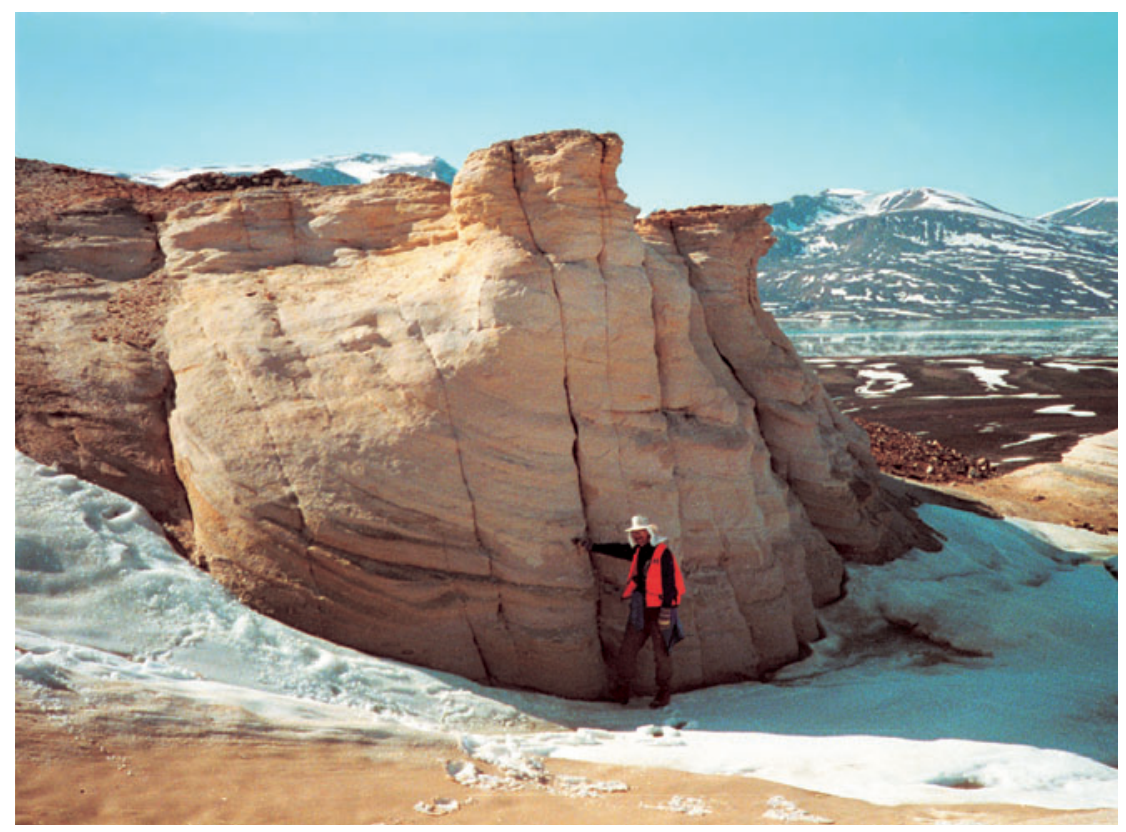

Fig. 20. Sandstone showing large-scale trough cross-bedding in the upper Payer Dal Formation. Bastians Dal, central Kuhn $\varnothing$. View towards the west.

The upper unit of the Payer Dal Formation consists mainly of fine- to medium-grained sandstone and is generally less cemented than the underlying shallow marine quartz sandstones of the lower unit and the Pelion Formation. The best section through the upper unit is section A (Figs 9A, 18; see also Surlyk 1977, fig. 4) where it consists of stacked successions of trough cross-bedded, fine- to medium-grained sandstones, commonly capped by oyster-rich, calcite-cemented, coarse-grained sandstones. Cross-bedded sandstones with sets up to $3 \mathrm{~m}$ thick and foresets commonly separated by single and double mud drapes occur in the upper part of the unit in section D, south Kingofjeld (Fig. 18). Palaeocurrent directions of the cross-beds of sections $\mathrm{A}$ and D are towards the S-SW.

In Bastians Dal, the lower Payer Dal Formation (possibly including the uppermost Pelion Formation) consists of a sandstone succession, c. $50 \mathrm{~m}$ thick, which forms a series of prominent benches separated by recessive slopes. The benches are composed of trough crossbedded, structureless and parallel laminated, calcitecemented sandstones, whereas the poorly exposed slopes appear to correspond to weakly cemented sandstones. The last sandstone bench that forms the top of the lower unit is capped by a thin persistent oyster bed overlain in many places by a thin pebble lag. The upper unit is composed of buff to yellow-red quartz sandstone; the exposed section is about $20 \mathrm{~m}$ thick. It shows large trough cross-sets at the base, up to $4 \mathrm{~m}$ thick, which grade up to small trough cross-sets in the upper- most metre (Fig. 20). The sandstones are well-sorted and composed of subangular to subrounded grains at the base of the coset, with more poorly sorted and angular grains towards the top. The cross-bedded sandstone unit is fine- to very coarse-grained and shows an overall coarsening-upwards trend. Palaeocurrents of the cross-beds are towards the south-west. The unit is not exposed above the coset of trough cross-beds, but is probably present west of the area beneath Quaternary alluvium deposits.

Palaeoenvironment. The Payer Dal Formation was deposited in a tidally-influenced environment as indicated by the abundance of cross-bedded sandstones with foresets separated by single and double mud drapes and the local occurrence of herringbone cross-bedding. The cross-bedded sandstones are interpreted to represent south-westwards migrating tidal bars or sandwaves in a shallow marine embayment (Surlyk 1977; Surlyk \& Clemmensen 1983).

Deposition of the siltstones and heteroliths that form the base of the lower unit in the Payer Dal area, took place in an offshore transition to offshore environment after drowning of the shallow marine sandstones of the Pelion Formation. Drowning was followed by shoreface progradation as reflected by the coarsening-upwards trend within the succession of siltstones, heteroliths and cross-bedded sandstones.

The pebbly sandstones with bivalves and belemnites at the top of the lower unit represent a composite lag 
deposit that is interpreted to have formed by transgressive wave ravinement of the underlying shallow marine sands. Drowning resulted in a deeper water regime as reflected by the generally finer grain size of the upper unit compared to the lower unit. The coset of cross-bedded sandstones which occurs at the base of the upper unit in the Bastians Dal area may represent a large, composite tidal sand bar which migrated towards the south-west.

\section{Bernbjerg Formation}

Facies. The Bernbjerg Formation covers much of the west side of Kuhn $\varnothing$ and has been estimated to have a stratigraphic thickness of $c .450 \mathrm{~m}$ on Kuhn $\varnothing$ (Figs 3, 7; Maync 1947; Surlyk 1977; Surlyk \& Clemmensen 1983). It is dominated by dark grey to black mudstones that are generally thin-bedded to laminated and weather to form a yellow-tan fissile mudstone. The sediments are generally rich in plant debris, ammonites, belemnites and locally the bivalve Buchia (Surlyk 1977). The formation overlies the Payer Dal Formation with a sharp boundary (see definition above). It is separated from overlying rift-climax sediments of the Wollaston Forland Group by an erosional, and locally angular, unconformity in the eastern part of the Wollaston Forland basin where elevated fault block crests were eroded, and by a conformity in the western down-tilted part of the block (Surlyk 1977, 1978b, 1991). On Kuhn Ø, the age of the Bernbjerg Formation ranges from Late Oxfordian - Kimmeridgian on the basis of ammonites and dinocysts.

The Bernbjerg Formation is readily subdivided into a lower heterolithic unit, the Ugpik Ravine Member of Surlyk (2003, this volume, fig. 5), and an upper unit dominated by uniform dark mudstones. In the Payer Dal area, the Ugpik Ravine Member is approximately $75 \mathrm{~m}$ thick (Surlyk 1977, figs 4, 24). It is of (?)Late Oxfordian Early Kimmeridgian age based on ammonites (Sykes \& Surlyk 1976; Surlyk 1977) and dinocysts. ${ }^{87} \mathrm{Sr} /{ }^{86} \mathrm{Sr}$ isotope values from a belemnite (Table 2) found a few metres above the base of the Bernbjerg Formation, indicate a latest Oxfordian - Early Kimmeridgian age (M. Engkilde, personal communication 1997). In section D, south Kingofjeld (Fig. 4), the Ugpik Ravine Member comprises seven coarsening-upwards heterolithic cycles, 5-14 m thick (Fig. 18). The lower part of each cycle typically consists of parallel to slightly undulating heterolithic laminae and thin beds. In the upper, more coarse-grained part, wave ripple and current ripple cross-lamination may occur. The cycles are separated by sharp erosional boundaries and, in some cases, by a lag rich in belemnites, wood fragments and wellrounded quartzite pebbles up to $4 \mathrm{~cm}$ in diameter.

The Ugpik Ravine Member is capped by a sharp surface where heterolithic sediments are succeeded by a succession of dark grey to black mudstones. This upper unit of the Bernbjerg Formation is estimated to be several hundred metres thick on Kuhn $\varnothing$ but was not measured or described in detail.

Palaeoenvironment. The sharp boundary at the base of the Bernbjerg Formation is interpreted as a major drowning surface formed during transgressive ravinement of the shallow marine sandstones of the underlying Payer Dal Formation. The coarsening-upwards heterolithic cycles in the Ugpik Ravine Member represent progradational events that resulted in progressive shallowing from the offshore to the lower or middle shoreface zone. The erosional boundaries and the localised lag deposits on top of the coarsening-upwards cycles are interpreted to have formed by transgressive reworking and winnowing. The sharp upper surface of the lower unit of the Bernbjerg Formation is interpreted as a major drowning surface marking the transition to offshore mudstones.

Geochemistry. Hydrogen index (HI) values of six mudstone samples from the Bernbjerg Formation fall in the range 32-143 mg HC/g TOC; TOC values range between $2.8 \%$ and $5.4 \%$. The low HI values are thought to be a consequence of the proximal setting, close to the cratonic mainland towards the west and north. Most of the Bernbjerg Formation samples contain plant debris or coal fragments.

\section{Thickness variations and sediment geometry}

In the Payer Dal region, the total thickness of the shallow marine sandstones of the Pelion and Payer Dal Formations varies from a minimum of $40 \mathrm{~m}$ at the crest of the fault-block to the east, to more than $350 \mathrm{~m}$ in Payer Dal itself and probably more than $500 \mathrm{~m}$ further west (Figs 7, 18). It is unclear if the thinning towards the east is due to onlap, depositional thinning, truncation or some combination of these. However, subtle bedding plane features seen on the aerial photographs and panoramas suggest that some of the thinning is due to eastwards onlap of the formations onto the peneplaned basement or the Bastians Dal Formation (Fig. 10A). The 


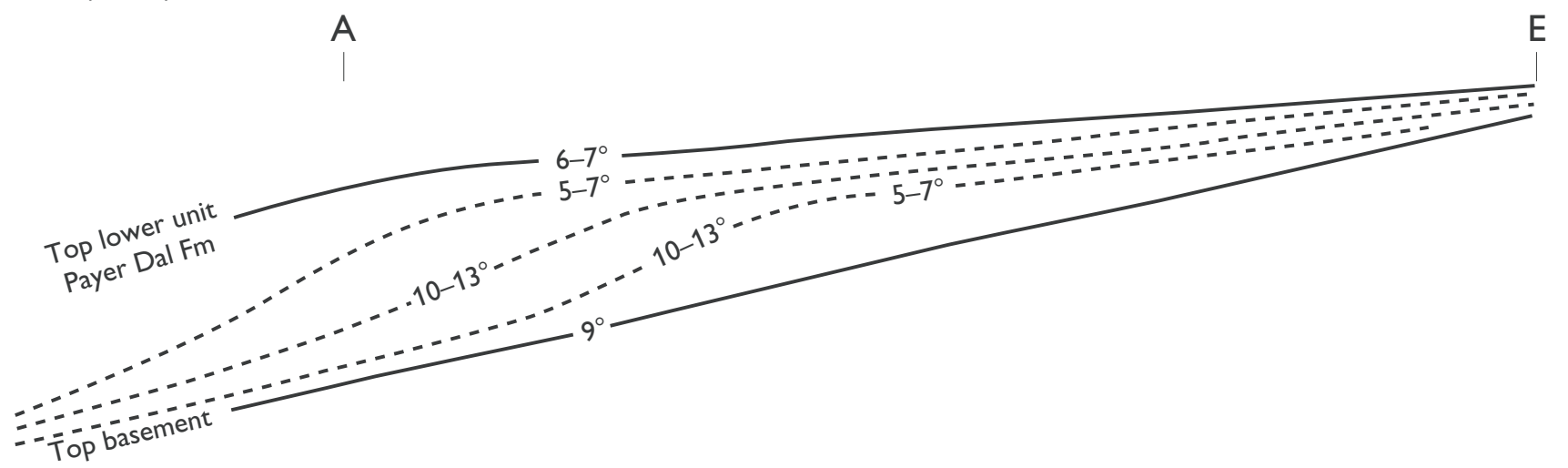

Fig. 21. Simplistic sigmoidal clinoform model constructed to explain structural data from south Kuhn $\varnothing$. The dips of the top of the lower Payer Dal Formation and the top basement surface are regional estimates based on calculations, whereas the slope angles of the dashed surfaces are based on measured dips from bedding planes at discrete localities. The higher dip values $\left(10-13^{\circ}\right)$ probably represent foresets of sand bars or, on a larger scale, the slopes of prograding clinoforms. The lower values $\left(5-7^{\circ}\right)$ probably represent beds deposited in a sub-horizontal attitude with superimposed post-depositional structural rotation. Sections $\mathbf{A}$ and $\mathbf{E}$ are $c$. $7 \mathrm{~km}$ apart; the lower Payer Dal Formation is c. $40 \mathrm{~m}$ thick in section E (Fig. 18).

depositional onlap probably reflects differential subsidence due to the onset of fault block tilting, possibly combined with eustatic sea-level rise. In this context, it is noteworthy that some very coarse-grained, poorly sorted sandstones occur in the Pelion Formation or the lower unit of the Payer Dal Formation in the east of the Payer Dal area, suggesting a proximal setting close to the sediment source (Figs 4, 18; section E, Schwarze Wand).

On south Kuhn $\varnothing$, the peneplaned surface of the basement has a regional strike of $160^{\circ}$ and a dip of $9^{\circ}$ to the WSW, mainly reflecting Jurassic and later fault block rotation. The top of the lower unit of the Payer Dal Formation has an average calculated regional strike of $160^{\circ}$ and a dip of $6-7^{\circ}$ to the WSW and represents a major drowning surface which was most likely close to horizontal at the time of deposition. Bedding planes within the Pelion Formation and the lower unit of the Payer Dal Formation dip 5-13 towards the WSW with an average strike of $165^{\circ}$.

The dip variations observed in the Pelion Formation and the lower Payer Dal Formation may be explained by a sigmoidal clinoform model (Fig. 21). The clinoform surfaces are represented by individual dips measured on bedding planes at discrete localities. The larger of these dips $\left(10-13^{\circ}\right)$ may represent foresets of sand bars or, on a larger scale, the slopes of prograding clinoforms. The smaller values $\left(5-7^{\circ}\right)$ probably represent beds originally closer to horizontal with superimposed post-depositional structural rotation. Clinoforms are dif- ficult to define in the field, with the exception of a locality near the crest of Schwarze Wand, where clinoforms dip up to $15^{\circ}$. A sigmoidal model explains the variability of dips and fits the interpreted depositional setting with numerous progradational events separated by drowning.

\section{Diagenesis}

The heterogeneous distribution of calcite cement and the abundance of concretions, especially in the Pelion Formation and the lower unit of the Payer Dal Formation, is a striking and characteristic feature of the shallow marine sandstones. Concretions range in size from a few centimetres to over $30 \mathrm{~cm}$ in diameter. Concretionary calcite-cemented zones typically follow bedding planes, but in some places cut vertically up section. The source of the calcite cement is probably biogenic carbonate derived from the abundant calcareous shelly fauna that is associated with the cemented sandstones. The high volumes of calcite cement (34-42\%) in several samples from the Pelion Formation and the lower Payer Dal Formation suggest that calcite precipitation took place at shallow to moderate burial depths. Concretionary zones along bedding planes are a common feature of similar age sandstones on the Norwegian continental shelf, and in onshore exposures in north-west Scotland and elsewhere in East Greenland (Fürsich 1982; Walderhaug et al. 1989; Bjørkum \& Walderhaug 1990). Bjørkum \& Walderhaug 
Fig. 22. Porosity and permeability of sandstones from the Pelion Formation and the lower Payer Dal Formation, Kuhn $\varnothing$. The bimodal distribution reflects the occurrence of cemented and poorly cemented sandstones (see Fig. 14B, C).

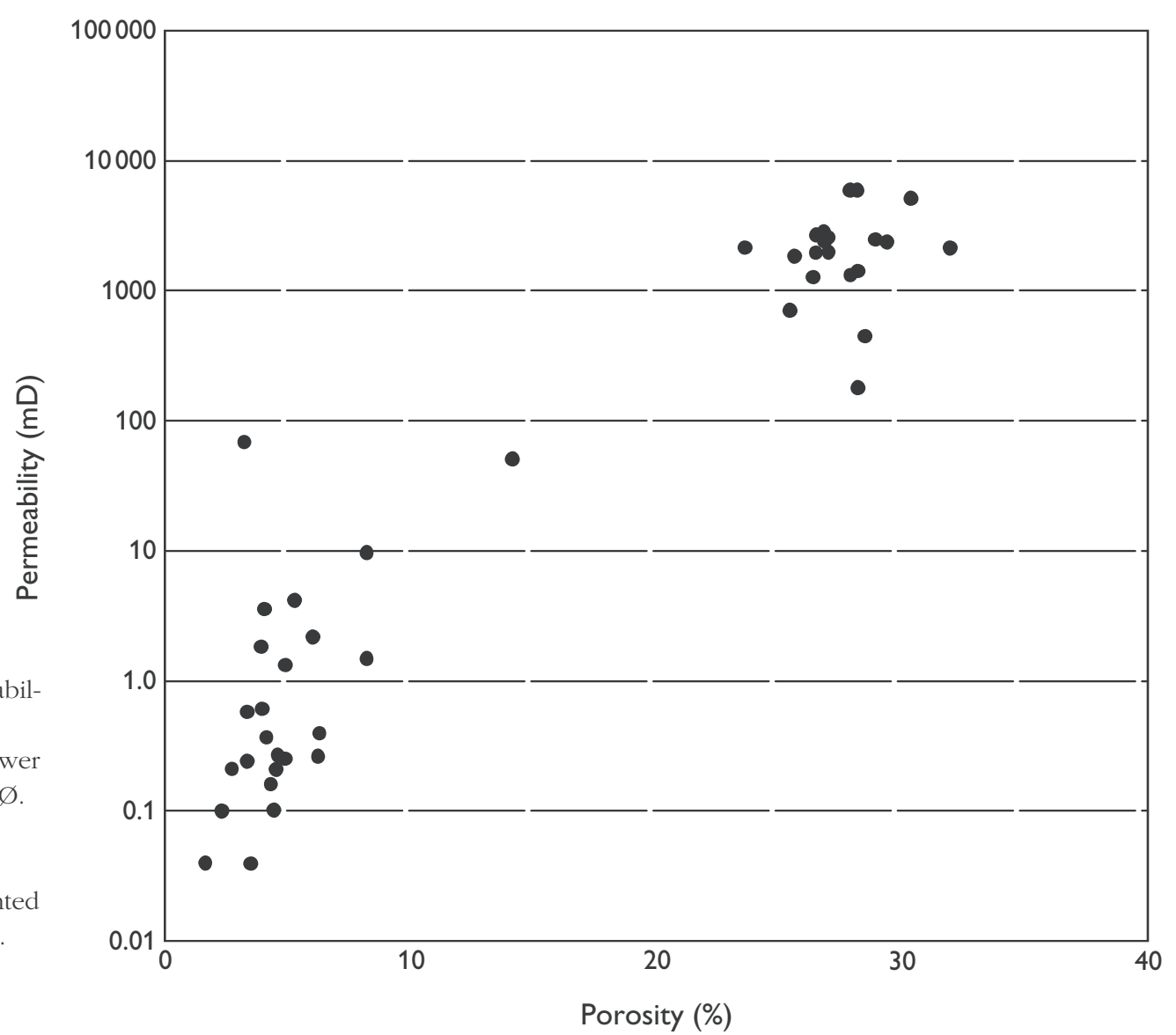

(1990) offered a detailed discussion of the nucleation and growth processes that create this fabric. Porosity and permeability measurements from core plugs taken from the sandstones of the Pelion and Payer Dal Formations reflect a strongly bimodal distribution of porosity and permeability between the cemented and weakly cemented sandstones (Figs 14B, C, 22).

Petrographic studies of sandstone samples from the upper Payer Dal Formation (Fig. 4, samples C-2, -16, $-17,-39,-40,-43,-51)$ show that the sandstones have undergone mechanical compaction, but have not been buried deeply enough to induce silica cementation. Measurements undertaken on some of the sandstones give helium porosity values of $28-32 \%$ and permeability values of $438-4900 \mathrm{mD}$.

The Jurassic sandstones from the Pelion and Payer Dal Formations of Kuhn $\varnothing$ are very similar to Jurassic sandstones found on the mid-Norwegian shelf and in the Barents Sea with regard to original mineralogical composition, sorting and grain size. A minor difference is that parts of the correlative Fangst Group of the midNorwegian shelf are coarser grained and contain less biogenic carbonate. Calcite cement is not as volumet- rically important in the Jurassic sandstones of the midNorwegian shelf as it appears to be in samples from Kuhn $\varnothing$. This is probably a function of the higher content of biogenic carbonate in the Kuhn $\varnothing$ samples. Quartz cement is typically extensive in the deeply buried sandstones of the Norwegian shelf, but is lacking in the samples from Kuhn $\varnothing$, suggesting that the Jurassic deposits of Kuhn $\varnothing$ have not been buried to depths where temperatures exceed $60-100^{\circ} \mathrm{C}$ (McBride 1989).

\section{Regional correlation}

Recognition of correlative regional surfaces in the Jurassic succession of the Wollaston Forland basin is difficult due to the abundance of local erosion surfaces in the tidal deposits and the restricted lateral extent of many of the outcrops. The most distinctive regional surfaces are the major drowning surfaces which separate the Jurassic succession into a series of backstepping sedimentary units reflecting the overall Middle-Late Jurassic transgression (Surlyk \& Clemmensen 1983; Surlyk 1991). Identification and tracing of the major drowning surfaces allow cor- 
产

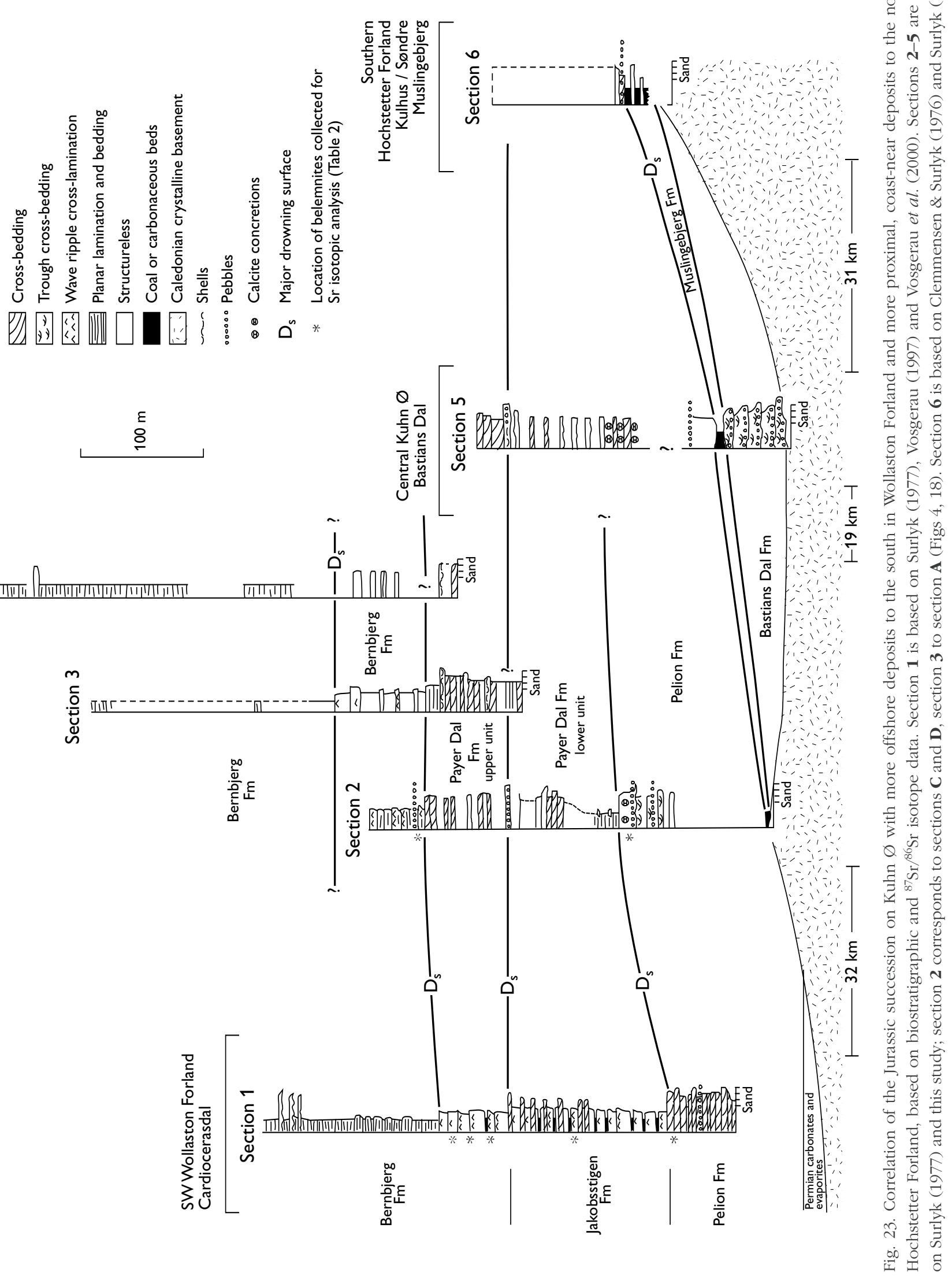


relation of the sedimentary units, in combination with biostratigraphic and ${ }^{87} \mathrm{Sr} /{ }^{86} \mathrm{Sr}$ isotope data. The major drowning surfaces are, however, difficult to recognise in both the most proximal landwards areas where nearshore sandstones occur both below and above the surfaces and in the most distal areas where the surfaces separate offshore mudstones. Biostratigraphic control is limited at some levels due to the scarcity of ammonites in the sandstones and the low diversity and generally low biostratigraphic resolution of the dinocyst assemblages.

Kuhn $\varnothing$ occupies an intermediate position between the generally more offshore deposits to the south in Wollaston Forland and the more proximal succession to the north in Hochstetter Forland (Fig. 6). The successions in Wollaston Forland and Hochstetter Forland are briefly described below and a correlation with the sections on Kuhn $\varnothing$ is suggested.

In the Cardiocerasdal area, in south-west Wollaston Forland, crystalline basement is overlain by a thin Permian succession of carbonates and evaporites but the contact with overlying Jurassic sediments is not well-exposed. Maync (1947) reported a coarse-grained lag, 3-4 m thick, rich in shells and logs occurring near the basement in Cardiocerasdal. It is interpreted as a composite transgressive lag formed by shallow marine winnowing during transgression of basal fluvial deposits equivalent to the Bastians Dal Formation. The occurrence of the ammonite Kepplerites tychonis Ravn at this level indicates a Late Bathonian age for the lag deposit (Maync 1947; Callomon 1993). In northern Wollaston Forland, the Pelion Formation rests directly on crystalline basement.

The basal part of the Pelion Formation is not well exposed in the Cardiocerasdal area and faulting makes thickness estimates uncertain. The uppermost $50 \mathrm{~m}$ of the formation are well-exposed, however, and consist of cross-bedded, tidally influenced sandstones showing S-SW palaeocurrent directions (Fig. 23). Calcite concretions are locally abundant, as observed in the sandstones of Kuhn $\varnothing$. The cross-bedded sandstones are interpreted to reflect shallow marine south-west migrating tidal bars or sandwaves (Surlyk 1977; Surlyk \& Clemmensen 1983). The Pelion Formation is separated from the overlying Jakobsstigen Formation by a major drowning surface which can be correlated with that at the top of the Pelion Formation on Kuhn $\varnothing$ (Fig. 23). On Kuhn $\varnothing$, this surface caps a regional, benchforming, carbonate-cemented sandstone and in the west Kingofjeld section it is overlain by siltstones and heteroliths of the lower Payer Dal Formation (Fig. 17). The age of this major drowning surface is not well-constrained but it probably developed in Late Callovian time as indicated by dinoflagellate cysts from sediments below and above the surface and by a few finds of ammonites in the middle part of the Jakobsstigen Formation in Cardiocerasdal (Fig. 23). The strontium isotopic ratios from belemnites from the uppermost Pelion Formation in the two areas are similar (Table 2) and indicate a Late or possibly a Middle Callovian age (M. Engkilde, personal communication 1997).

The Jakobsstigen Formation is c. $130 \mathrm{~m}$ thick in Cardiocerasdal. It is of Early-Middle Oxfordian age, but the dating is not well-constrained. The formation consists of rhythmically interbedded coastal plain and shallow marine deposits (Bojesen-Koefoed et al. 1997; Vosgerau et al. 2000). The Jakobsstigen Formation is capped by the next major drowning surface which is thought to correlate with the surface separating the lower and upper units of the Payer Dal Formation on Kuhn $\varnothing$ (Fig. 23). The presence of coastal plain deposits within the Jakobsstigen Formation is indicative of deposition in a more up-dip position on the hangingwall than that represented by the cross-bedded tidal sandstones of the Payer Dal Formation.

In Cardiocerasdal, the Jakobsstigen Formation is overlain by a strongly bioturbated, faintly wave and current rippled heterolithic unit, $c .55 \mathrm{~m}$ thick, deposited in the shallow offshore zone, and forming the basal part of the Bernbjerg Formation. Ammonites indicate the Upper Oxfordian Amoeboceras glosense Chronozone (Fig. 23), and ${ }^{87} \mathrm{Sr} /{ }^{86} \mathrm{Sr}$ isotope values from three belemnites (Table 2) indicate a Late Oxfordian age (M. Engkilde, personal communication 1997). It is capped by a major drowning surface of late Amoeboceras glosense Chron age; this zone extends a few metres above the drowning surface. The drowning surface is correlated with the major drowning surface separating the upper unit of the Payer Dal Formation and the Bernbjerg Formation on Kuhn $\varnothing$ (Fig. 23). In Cardiocerasdal, the succession above this drowning surface consists of more than $200 \mathrm{~m}$ of offshore mudstones of the Bernbjerg Formation.

The Jurassic succession on Hochstetter Forland was deposited at the head of the embayment in a more proximal setting than the succession on Kuhn $\varnothing$ (Fig. 6). It overlies Upper Proterozoic dolomites on the southwest side of Søndre Muslingebjerg, a few kilometres south-east of Kulhus. Coal-bearing sediments of the Muslingebjerg Formation occur in an isolated downfaulted block at Kulhus in southern Hochstetter Forland (Clemmensen \& Surlyk 1976; Petersen et al. 1998). The lower boundary is not exposed but the formation is con- 
sidered to be c. $20 \mathrm{~m}$ thick. It consists of four coal beds, up to $3.5 \mathrm{~m}$ thick, interbedded with lagoonal and subordinate shoreface sediments. Only one coal bed occurs at Søndre Muslingebjerg. It is c. $0.15 \mathrm{~m}$ thick and is situated c. $3 \mathrm{~m}$ above basement. The coal beds at Kulhus thus wedge out towards the south-east within a distance of a few kilometres. Dinoflagellate cysts from marine sediments immediately above the uppermost coal bed at Kulhus indicate the top Upper Callovian $P$. athleta Chronozone (Fig. 23). The coal-bearing deposits of the Muslingebjerg Formation are overlain by a poorly exposed succession of shallow marine sandstones, $c$. $100 \mathrm{~m}$ thick, referred to the Payer Dal Formation. The top of the sandstone succession is dated by ammonites to the Upper Oxfordian, Amoeboceras glosense or Amoeboceras serratum Chronozone (Fig. 23; Sykes \& Surlyk 1976). Further north in Hochstetter Forland, small outcrops of Lower Kimmeridgian offshore mudstones have been reported (Surlyk 1978a).

\section{Summary and conclusions}

Kuhn $\varnothing$ offers an excellent study locality of MiddleUpper Jurassic early syn-rift stratigraphy in a half-graben setting. The Jurassic succession rests directly on the peneplaned surface of the crystalline basement. The main geometrical features are a marked thickening of the Jurassic from the eastern crestal area into the graben to the west and eastwards onlap onto the crystalline basement peneplain. The main conclusions are as follows.

1. Five Jurassic early rift formations are recognised below the rift-climax Wollaston Forland Group on Kuhn $\varnothing$. They include the Bastians Dal (new) and Muslingebjerg Formations of Middle Jurassic age, the Pelion Formation (revised) of Late Bathonian Late Callovian age, the Payer Dal Formation (new) of Early - early Late Oxfordian age, and the Bernbjerg Formation of (?)Late Oxfordian - Kimmeridgian age.

2. The Bastians Dal Formation consists of a succession of fluvial conglomerates and pebbly sandstones up to $150 \mathrm{~m}$ thick. On central Kuhn $\varnothing$, the coarsegrained deposits are interpreted to fill an incised valley system, probably of Early and early Middle Jurassic age. On southern Kuhn $\varnothing$, the unit is thinner, possibly because the exposures are located at the margin of the valley system. The position of the incised valley system was probably controlled by zones of structural weakness. The fluvial conglom- erates and sandstones were deposited during early base-level rise. During continuing and possibly accelerating base-level rise, the fluvial environments became covered with peat swamps shortly before the valley was completely filled. Eventually the valley and the adjacent interfluves were flooded, probably in Late Bathonian - Early Callovian times.

3. Coals of the Muslingebjerg Formation on south Kuhn $\varnothing$ comprise kerogen types II-III, contain over 50\% TOC and give high hydrogen index values (up to $700 \mathrm{mg} \mathrm{HC} / \mathrm{g}$ TOC), thus indicating that they represent a good oil-prone source rock.

4. The Pelion Formation on Kuhn $\varnothing$ is interpreted to reflect deposition in the lower to upper shoreface based on the dominance of evenly laminated, swaley cross-stratified, or strongly bioturbated fine- to medium-grained sandstones alternating with wave rippled or trough cross-bedded, medium- to coarsegrained sandstones.

5. The Payer Dal Formation is subdivided into two units separated by a major drowning surface. The formation is dominated by trough cross-bedded sandstones formed by migration of shallow marine tidal sandwaves and sand bars towards the S-SW. The generally finer grain size of the upper unit of the formation suggests a deeper water setting than that represented by the Pelion Formation and the lower unit of the Payer Dal Formation.

6. The Pelion and Payer Dal Formations are petrographically very similar to Jurassic sandstones from the mid-Norwegian shelf and the Barents Sea with regard to original mineralogical composition, sorting and grain size. However, the Pelion and Payer Dal Formations have not been buried to sufficient depths to induce silica cementation. Porosity and permeability data from the Pelion Formation and the lower unit of the Payer Dal Formation show a strongly bimodal distribution between calcitecemented and weakly-cemented quartz sandstones. The calcite cement was probably derived from carbonate fossils and developed into concretionary fabrics. The upper unit of the Payer Dal Formation is generally a weakly-cemented quartz sandstone with helium porosities around 30\%.

7. The Bernbjerg Formation mudstones are comparable to the Upper Jurassic source rock of the mid- 
Norwegian shelf, but give low HI values (32-143 mg $\mathrm{HC} / \mathrm{g}$ TOC) reflecting the proximal setting relative to the cratonic mainland to the west.

8. The most distinct regional key stratigraphic surfaces are the major drowning surfaces which separate the Jurassic package into a succession of backstepping sedimentary units. Identification and tracing of the major drowning surfaces in combination with biostratigraphic and ${ }^{87} \mathrm{Sr} /{ }^{86} \mathrm{Sr}$ isotope data allow correlation of the sedimentary units within the Wollaston Forland basin. In proximal settings, however, shallow marine sandstones may occur both below and above the major drowning surfaces making it difficult or impossible to distinguish the sedimentary units.

\section{Acknowledgements}

P.C. Alsgaard and V.L. Felt are grateful to their main sponsor Amoco Norway Oil Company who also gave them permission to publish, and to Statoil and the other Wollgan partners who let Amoco participate in the project. We thank the following colleagues for biostratigraphic and isotope stratigraphic information: D.G. Benson and S. Piasecki (palynology), J.A. Bergen and J.R. Groves (nannoplankton and foraminifera), J.H. Callomon (ammonites), and M. Engkilde ( $\mathrm{Sr}$ isotopes). Statoil and Saga are thanked for providing dinoflagellate cyst data from the Pelion, Jakobsstigen, and Bernbjerg Formations in the Cardiocerasdal area. Petrography was performed by $\mathrm{O}$. Walderhaug and $\mathrm{L}$. Bonnell of Rogaland Research. Core analysis was done by D. Russel of Schlumberger Geoquest, and source rock analysis by G. von Graas of Statoil and I.L. Ferriday of Geolab Nor. G. Artigas and other Amoco employees gave valuable contributions to the article. We are grateful to A.G. Whitham, T. Olsen and especially J.R. Ineson for constructive and helpful reviews. S. Broen-Jensen was an effective base camp manager; we thank him and the Sirius Sledge Patrol for their help. Support to F. Surlyk from the Danish Natural Science Research Council is gratefully acknowledged.

\section{References}

Bjørkum, P.A. \& Walderhaug, O. 1990: Geometrical arrangement of calcite cementation within shallow marine sandstones. Earth-Science Reviews 29, 145-161.
Bojesen-Koefoed, J.A., Christiansen, F.G., Petersen, H.I., Piasecki, S., Stemmerik, L. \& Nytoft, H.P. 1996: Resinite coals of northeast Greenland - a hitherto unrecognised, highly oil-prone Jurassic source rock. Canadian Petroleum Geology Bulletin 44 458-473.

Bojesen-Koefoed, J.A., Petersen, H.I., Surlyk, F. \& Vosgerau, H. 1997: Organic petrography and geochemistry of inertinite-rich mudstones, Jakobsstigen Formation, Upper Jurassic, northeast Greenland: indications of forest fires and variations in relative sea-level. International Journal of Coal Geology 34, 345-370.

Callomon, J.H. 1993: The ammonite succession in the Middle Jurassic of East Greenland. Bulletin of the Geological Society of Denmark 40, 83-113.

Cant, D.J. \& Walker, R.G. 1976: Development of a braided fluvial facies model for the Devonian Battery Point Sandstone, Quebec. Canadian Journal of Earth Sciences 13, 102-119.

Clemmensen, L.B. \& Surlyk, F. 1976: Upper Jurassic coal-bearing shoreline deposits, Hochstetter Forland, East Greenland. Sedimentary Geology 15, 193-211.

Engkilde, M. \& Surlyk, F. 2003: Shallow marine syn-rift sedimentation: Middle Jurassic Pelion Formation, Jameson Land, East Greenland. In: Ineson, J.R. \& Surlyk, F. (eds): The Jurassic of Denmark and Greenland. Geological Survey of Denmark and Greenland Bulletin 1, 813-863 (this volume).

Fürsich, F.T. 1982: Rhythmic bedding and shell bed formation in the Upper Jurassic of East Greenland. In: Einsele, G. \& Seilacher, A. (eds): Cyclic and event stratification, 208-222. Berlin: Springer Verlag.

Jones, C.E., Jenkyns, H.C., Coe, A.L. \& Hesselbo, S.P. 1994: Strontium isotopic variations in Jurassic and Cretaceous seawaters. Geochimica et Cosmochimica Acta 58, 3061-3074.

Koch, L. 1955: Report on the expeditions to central East Greenland 1926-1939, conducted by Lauge Koch. Part II. Meddelelser om Grønland 143(2), 642 pp.

Koch, L. \& Haller, J. 1971: Geological map of East Greenland $72^{\circ}-76^{\circ} \mathrm{N}$. Lat. (1:250 000). Meddelelser om Grønland 183, 26 pp, 13 maps.

Maync, W. 1947: Stratigraphie der Jurabildungen Ostgrönlands zwischen Hochstetterbugten $\left(75^{\circ} \mathrm{N}\right)$ und dem Kejser Franz Joseph Fjord $\left(73^{\circ} \mathrm{N}\right)$. Meddelelser om Grønland 132(2), $223 \mathrm{pp}$.

McBride, E.F. 1989: Quartz cement in sandstones: a review. EarthScience Reviews 26, 69-112.

Miall, A.D. 1977: A review of the braided river depositional environment. Earth-Science Reviews 13, 1-62.

Petersen, H.I., Bojesen-Koefoed, J.A., Nytoft, H.P., Surlyk, F., Therkelsen, J. \& Vosgerau, H. 1998: Liptinite-enriched coal facies cycles and sequence stratigraphy of a paralic coal-bearing succession, Middle Jurassic, Hochstetter Forland, NorthEast Greenland. International Journal of Coal Geology 36, 1-30.

Piasecki, S. \& Stemmerik, L. in press: Jurassic dinoflagellate cysts from Hochstetter Forland, North-East Greenland. In: Stemmerik, L. \& Stouge, S. (eds): The Jurassic of North-East Greenland. Geological Survey of Denmark and Greenland Bulletin.

Piasecki, S., Callomon, J.H. \& Stemmerik, L. in press: Jurassic dinoflagellate cyst stratigraphy of Store Koldewey, North-East Greenland. In: Stemmerik, L. \& Stouge, S. (eds): The Jurassic of North-East Greenland. Geological Survey of Denmark and 
Greenland Bulletin.

Surlyk, F. 1977: Stratigraphy, tectonics and palaeogeography of the Jurassic sediments of the areas north of Kong Oscars Fjord, East Greenland. Bulletin Grønlands Geologiske Undersøgelse 123, $56 \mathrm{pp}$.

Surlyk, F. 1978a: Mesozoic geology and palaeogeography of Hochstetter Forland, East Greenland. Bulletin of the Geological Society of Denmark 27, 73-87.

Surlyk, F. 1978b: Submarine fan sedimentation along fault scarps on tilted fault blocks (Jurassic-Cretaceous boundary, East Greenland). Bulletin Grønlands Geologiske Undersøgelse 128, 108 pp.

Surlyk, F. 1990: Timing, style and sedimentary evolution of Late Palaeozoic - Mesozoic extensional basins of East Greenland. In: Hardman, R.P.F. \& Brooks, J. (eds): Tectonic events responsible for Britain's oil and gas reserves. Geological Society Special Publication (London) 55, 107-125.

Surlyk, F. 1991: Sequence stratigraphy of the Jurassic - lowermost Cretaceous of East Greenland. American Association of Petroleum Geologists Bulletin 75, 1468-1488.

Surlyk, F. 2003: The Jurassic of East Greenland: a sedimentary record of thermal subsidence, onset and culmination of rifting. In: Ineson, J.R. \& Surlyk, F. (eds): The Jurassic of Denmark and Greenland. Geological Survey of Denmark and Greenland Bulletin 1, 659-722 (this volume).

Surlyk, F. \& Clemmensen, L.B. 1983: Rift propagation and eustacy as controlling factors during Jurassic inshore and shelf sedimentation in northern East Greenland. Sedimentary Geology 34, 119-143.
Sykes, R.M. \& Surlyk, F. 1976: A revised ammonite zonation of the Boreal Oxfordian and its application in Northeast Greenland. Lethaia 9, 421-436.

Vischer, A. 1943: Die postdevonische Tektonik von Ostgrönland zwischen $74^{\circ}$ und $75^{\circ} \mathrm{N}$. Br., Kuhn $\varnothing$, Wollaston Forland, Clavering $\varnothing$ und angrenzende Gebiete. Meddelelser om Grønland 133(1), 195 pp.

Vosgerau, H. 1997: Depositional environments and sequence stratigraphy of a Middle-Upper Jurassic early syn-rift succession deposited in a low gradient epeiric seaway, the Wollaston Forland Basin, Northeast Greenland 1-3, 110 pp. Unpublished Ph.D. thesis, University of Copenhagen, Denmark.

Vosgerau, H., Bojesen-Koefoed, J.A., Petersen, H.I. \& Surlyk, F. 2000: Forest fires, climate and sea-level changes in a coastal plain - shallow marine succession (Early-Middle Oxfordian Jakobsstigen Formation, North-East Greenland). Journal of Sedimentary Research 70, 408-418.

Vosgerau, H., Larsen, M., Piasecki, S. \& Therkelsen, J. in press: A new Middle-Upper Jurassic succession of Hold with Hope, North-East Greenland. In: Stemmerik, L. \& Stouge, S. (eds): The Jurassic of North-East Greenland. Geological Survey of Denmark and Greenland Bulletin.

Walderhaug, O., Bjørkum, P.A. \& Nordgård Bolås, H.M. 1989: Correlation of calcite-cemented layers in shallow-marine sandstones of the Fensfjord Formation in the Brage Field. In: Collinson, J.D. (ed.): Correlation in hydrocarbon exploration, 367-375. London: Graham \& Trotman for the Norwegian Petroleum Society (NPF). 